\title{
Protein analysis in human cerebrospinal fluid: Physiological aspects, current progress and future challenges
}

\author{
Andreas F. Hühmer ${ }^{\mathrm{a}, *}$, Roger G. Biringer ${ }^{\mathrm{a}}$, Heidi Amato ${ }^{\mathrm{b}}$, Alfred N. Fonteh ${ }^{\mathrm{b}}$ and \\ Michael G. Harrington ${ }^{\mathrm{b}}$ \\ ${ }^{a}$ Proteomics, Finnigan Mass Spectrometry, Thermo Electron, San Jose, CA 95134, USA \\ ${ }^{\mathrm{b}}$ Molecular Neurology Program, Huntington Medical Research Institutes. Pasadena, CA 91101, USA
}

\begin{abstract}
The introduction of lumbar puncture into clinical medicine over 100 years ago marks the beginning of the study of central nervous system diseases using the human cerebrospinal fluid (CSF). Ever since, CSF has been analyzed extensively to elucidate the physiological and biochemical bases of neurological disease. The proximity of CSF to the brain makes it a good target for studying the pathophysiology of brain functions, but the barrier function of the CSF also impedes its diagnostic value. Today, measurements to determine alterations in the composition of CSF are central in the differential diagnosis of specific diseases of the central nervous system (CNS). In particular, the analysis of the CSF protein composition provides crucial information in the diagnosis of CNS diseases. This enables the assessment of the physiology of the blood-CSF barrier and of the immunology of intrathecial responses. Besides those routine measurements, protein compositional studies of CSF have been extended recently to many other proteins in the expectation that comprehensive analysis of lower abundance CSF proteins will lead to the discovery of new disease markers. Disease marker discovery by molecular profiling of the CSF tissue has the enormous potential of providing many new disease relevant molecules. New developments in protein profiling techniques hold promise for the discovery and validation of relevant disease markers. In this review, we summarize the current efforts and progress in CSF protein profiling measurements using conventional and current protein analysis tools. We also discuss necessary development in methodology in order to have the highest impact on the study of the molecular composition of CSF proteins.
\end{abstract}

\section{Introduction}

Cerebrospinal fluid (CSF), the fluid surrounding the central nervous system (CNS), has great clinical and basic scientific importance. CSF is in equilibrium with the brain and spinal cord and its extra cellular fluid, and therefore it reflects the state of health and activity of the CNS. CSF offers valuable, though indirect, access to characterize the physiology of the brain and its malfunctions. Analysis of the CSF offers the most direct and innocuous method of assessing the chemical and cellular environment of the CNS in the living pa-

\footnotetext{
*Corresponding author: Andreas F. Hühmer, PhD., Proteomics, Finnigan Mass Spectrometry, San Jose, CA 95134, USA. Tel.: +1 408965 6000; E-mail: andreas.huhmer@thermo.com.
}

tient. Much evidence exists to support the notion that CSF is an extension of the brain and its extra cellular fluid (ECF). Physiologic compartmentalization effectively isolates the CNS from the rest of the body and isolation not only provides protection of its delicate function from harmful mechanical impact, but it also impedes its diagnostic evaluation. The role of CSF as a connective tissue between the brain and the bloodstream and its potential to reflect the physiology of the brain provides the motivation for mining this fluid for unique markers. Disease markers are needed for elucidating pathophysiological events and providing novel avenues for diagnostic and therapeutic intervention.

CSF has been used for diagnostic purposes for more than 100 years and for most of this time the CSF was almost exclusively studied by clinicians, neurosurgeons 
and neurologists. Recognizing the diagnostic potential of CSF for studying the pathophysiology of the brain, more recently neurochemists and neurobiologists have brought a number of new methodologies and tools for the analysis and characterization of CSF to bear. In particular, for the study of the molecular composition of CSF a number of new high-throughput protein analysis tools are now widely used with the expectation that the highly parallel analysis of CSF helps to gain more insight into dynamic changes of the CNS. Technological developments in analytical separation methods and, in particular in mass spectrometry and related areas provide researchers today with the ability to detect hundreds of proteins at very low levels. The dramatically increased power of new analytical technologies together with innovative bioinformatics approaches for mining massive amounts of data promises to provide a more comprehensive picture of proteins and changes in protein isoforms in the CSF.

We believe that the emerging tools for the study of CSF proteins will afford a comprehensive representation of dynamic changes in CSF, as well as contribute to the understanding of molecular changes that directly reflect disease states in the brain. It appears reasonable to assume that the availability of more sensitive and powerful detection technologies provide a potent extension of current diagnostic tools. More ambitiously, it is the hope that the new analytical capabilities will reduce uncertainty in current measurements and also improve the prognostic value of CSF diagnostics in the future. However, based on the simplistic assumption that CSF functions as a fluid reservoir of highly diluted brain extracellular fluid in steady-state equilibrium with the adjacent brain tissue and bloodstream, most CSF protein measurements have been carried out using approaches that more resemble the determination of trace contaminants in a glass of water. But is disease marker discovery and the understanding of underlying disease mechanisms in reality only a question of analytical sensitivity? It is our hypothesis that successful discovery of disease markers requires the parallel study and comprehensive analysis of all components of the CSF tissue. This includes the measurements of proteins, lipids, small molecules, ions that contribute to the basic physiological functions of CSF. The availability of more sensitive tools for the compositional measurements is not necessarily the only limiting factor, but such improvements will enable scientists and clinicians to more fully understand the function and molecular organization of CNS functions. Moreover, we expect that CSF measurements will reveal CSF as an important milieu, which has to be understood in its function before we can exploit CSF tissue as a reservoir for brain-derived disease markers and the elucidation of CNS diseases. Current profiling efforts have brought us already closer to a more comprehensive picture of the intricacy of dynamic human CSF tissue that will certainly help in the discovery and validation of CNS specific disease markers discovery in the future.

It is the purpose of this review to summarize and critically review the progress and impact of current protein measurements on the study of the compositional profiling of CSF. Specifically, we summarize results from clinically focused protein measurements in CSF and compare them to protein compositional studies described in recent proteomics experiments. It is not the intent of this review to compare different protein profiling technologies. Excellent reviews have been published recently on this subject [1-4]. The scope of this paper is to update the reader on the research in CSF protein compositional studies and is therefore not addressing issues of the practicing clinicians interested in CSF protein analysis of infectious diseases, bacteriology and virology of the CNS. This review also provides a brief description of the physiology, the fluid dynamics and the biochemistry of human CSF to help the reader understand the significance of current CSF protein measurements and consequences of future findings. However, CSF is a complex, interconnected tissue and a complete summary of the physiology in the context of this review is not feasible. A more thorough treatment of this subject can be found elsewhere [5, 6]. We further demonstrate in this review that protein discovery in CSF is not simply a question of the availability of sensitive analytical tools for the detection of small amounts of low abundance proteins in CSF, but also the availability of new bioinformatic approaches that enable us to interpret results of sensitive mass spectrometry measurements. Results of current CSF protein profiling efforts indicate that relatively few measurements have produced new findings that provide insights and indicate the beginning of answers into the functions and dysfunctions of CNS.

\section{Physiology of the cerebrospinal fluid}

Protein analysis by molecular profiling of CSF tissue has the enormous potential for the discovery of molecules that are relevant to disease. However, the various analytical challenges that need to be addressed to deliver on the promise are only part of the overall 
challenge. It is our belief that significant progress in CSF compositional profiling for disease marker discovery needs a systematic approach that combines new analytical tools with a clear understanding of CSF physiology. The current understanding of the physiology and function of the CSF as a specialized connective tissue are, therefore, crucial to the successful and meaningful analysis of molecular changes in the CNS. In this context a brief summary of the physiology of CSF is provided together with a short review of the protein biochemistry of CSF.

\subsection{Source of $C S F$}

Cerebrospinal fluid is mainly produced in the choroid plexus, a leaf-like structure protruding into the lateral, third, and fourth ventricles of the brain. A small amount of CSF fluid is also believed to originate from the extracellular space of the brain which is added to the CSF at various locations of the ventricular system. The mechanism by which the extracellular fluid (ECF) progresses from the brain into the CSF is bulk flow, carrying substances at equal rates to the CSF, independent of their molecular properties. The CSF formed then passes through cisternea, the interventricular formina into the third ventricle, then the fluid flows through the cerebral aqueduct into the fourth ventricle and then accumulates in the subarachnoid space (SAS) covering the cerebrum and also the spinal cord. The SAS extends superficially over the whole surface of the brain and spinal cord. After bathing the surface of the spinal cord and the base of the brain, CSF passes upward over the convexity of the hemispheres to be absorbed into the intracranial venous sinuses. CSF removal from the SAS is largely accomplished by the absorption of CSF by arachnoid villi in a valve-like process, permitting the unidirectional flow of CSF from SAS into the venous sinuses. CSF absorption is driven by a positive pressure in the microvilli that needs to exceed the pressure within the sinuses. Electron microscopic studies demonstrated vacuoles within the cells of the villi, which suggested that there is a dynamic system of transcellular channels or pores which allow the bulk outflow of CSF across the mesothelial barrier. However, more recently, studies on a number of species, including humans have shown that the lymphatic drainage pathway also may play an important role for CSF clearance. Dye distribution patterns in neonatal lambs illustrated the important role in which cranial and spinal nerves link the subarachnoid compartment with extracranial lymphatics $[7,8]$. There is mounting evidence that a significant portion of cerebrospinal fluid drainage is associated with transport along cranial and spinal nerves with absorption taking place into lymphatic vessels external to the CNS. In neonatal lambs, quantitative evidence suggests that a significant volume of cranial CSF drainage is associated with transport along olfactory nerves with absorption primarily into extracranial lymphatics in the paranasal region [8]. At this time, it is unclear to what extent this drainage path in humans plays a role in the clearance of CSF from SAS.

\subsection{Functions of CSF}

Four major physiological functions for the CSF have been defined; the physical support of the CNS, the excretory function and sink action of the brain, intracerebral transport and the control of the chemical environment of the CNS. The cerebrospinal fluid in the subarachnoid space plays a supportive role for the brain, providing physical support or buoyancy for the brain. The CSF is also important in protecting the brain from the acute changes in central venous pressure. It is apparent that an actively secreted, constantly renewed fluid with a tightly regulated composition must have other functions as well. A normal human can absorb CSF at a rate up to six times the normal rate of CSF formation with only a moderate increase in intracranial pressure. The combination of bulk absorption of solute and solvent by the arachnoid villi and the selective removal of molecules by the choroid plexus is termed the sink function of the CSF. The continuous secretion of CSF from choroid plexus and re-absorption of CSF back into the circulation creates a continuous flow of CSF through the ventricular system and the SAS reducing the steady state concentration of molecules in the CSF with a secondary sink effect for brain-derived molecules in ECF. In the absence of a lymphatic system in the CNS that could return solutes in the ECF of the brain to the blood plasma independent of their relative concentrations, the brain might have evolved this mechanism for effective turnover of ECF. In fact, experiments with tracer substances introduced into the CSF demonstrate exchange between the interstitial ECF of the brain and spinal cord, implying that the CSF is in continuity with the interstitial fluid of the CNS providing an effective control mechanism for the ECF of the brain [9]. The sink effect is particularly large for molecules such as lipid-insoluble molecules that penetrate barriers more slowly. This implies that molecules reaching the interstitial fluid of the brain may diffuse into CSF and then be removed by bulk absorption or 
active transport into the venous blood. Bulk exchange of CSF with interstitial fluid and distribution throughout the brain along the perivascular spaces, driven by the pulsation of the vascular tree have been proposed as the mechanism for distribution of compounds from CSF through the brain. Within the limits imposed by the laws of diffusion and the effect of CSF bulk flow, the CSF could "deliver" neuroactive substances to other parts of the brain. However, in the absence of a control mechanism other than the unidirectional flow provided by the sink action of the CSF itself, those active substances probably have a very specific target within the CNS. The target of neuroactive substances could be proteins within the CSF or sites at the barriers separating the blood, brain and CSF compartments.

Considering the various functions of the CSF, some of which might not have been discovered yet, the expectation for disease marker discovery in CSF is that a small portion of the CSF composition reflects the composition of the brain interstitial fluid and the adjacent cerebral tissue. The effective sink action of the CSF helps to maintain low concentration of many substances in the brain, including those that are derived from the normal brain cell cycle as well as molecules derived from diseased tissue that might serve as the source of disease markers. Many of those molecules originating from pathological mechanisms in the brain are subject to this sink effect and successful discovery of disease markers is most likely accomplished by studying the molecular composition of CSF.

\section{Biochemistry of CSF}

\subsection{Composition of cerebrospinal fluid}

Soon after the introduction of lumbar puncture into clinical medicine the CSF composition has been analyzed extensively to elucidate the physiological and biochemical bases of neurological diseases. The CSF composition is characterized as a water-like, crystal clear, colorless fluid with very few cells ( $0-4$ cells $/ \mu \mathrm{L})$, and a low protein content $(0.2 \%$ of blood total protein) and salt concentrations comparable to blood $[5,10]$. Besides soluble components, such as proteins, small molecules and ions, CSF contains a number of cells and other cellular components. Although, the study of cellular elements in CSF comprises a rich source of diagnostic indicators for neurological diseases, it is beyond the scope of this article to discuss CSF-derived cells or cellular components as a potential source of disease markers. Similarly, cerebrospinal fluid sediments that are largely derived from proteins and might be considered part of the CSF protein contents are not reviewed here [10].

\subsection{CSF tissue boundaries}

The CSF connective tissue is clearly defined in its compositional content by the relations of CSF and its compartment boundaries. Two major barriers, the blood-brain barrier and the blood-CSF barrier define the major entry and exit routes of components into the CNS from the circulation. The choroid plexus barrier (blood-CSF epithelium barrier) represents the only direct entry route for molecular components from blood into the CSF tissue, whereas the CSF-blood arachnoid barrier is the dominant path for molecules to the venous circulation. The boundaries of the CSF tissue within the CNS are given by the ependyma cell barrier in the brain ventricles and the pia matter in the SAS. The equilibrium exchange of molecules of the CSF tissue with the brain extracellular fluid or the blood is clearly influenced by those barriers and plays a major role in the composition and the compositional change of the $\mathrm{CSF}$ tissue. The nature of the barriers surrounding the CSF tissue and their dual role in allowing access to the brain as well as providing passage from the CNS to the blood however, impose a rather complex dynamics on the compositional change of CSF.

The complexity of CSF composition arises from the differences in barrier physiology and their collective effect on the molecular composition of CSF. The various barriers from and to CSF tissue have diverse properties with respect to their mechanism allowing molecules to pass from one side of the barrier to another, i.e., active versus passive transport mechanism, but also with respect to their molecular selectivity. For some barriers, e.g., choroid plexus and the arachnoid villi, mechanisms for molecular passage from and to the CSF have been established, but drainage paths into the extracranial lymphatic system are largely uncharacterized at this point. Large molecules fail to enter the CSF from the blood because of the interposition of the vascular endothelium (the blood-CSF barrier), but there is a rapid exchange of small molecular weight substances between the CSF and the extracellular fluid of the brain and spinal cord. Superimposed on the diffusion restrictions provided by the tight junction in the blood-CSF barrier is a series of transport mechanisms into and out of the CSF that determines and controls the internal environment of the brain with respect to a wide range 
of molecules, such as electrolytes, amino acids, glucose, vitamins, peptides and proteins. Substances important for brain metabolism and maintenance of CSF electrolytes, such as glucose, amino acids, and cations are transported by carrier-mediated processes.

A prerequisite for normal nerve impulse transmission, the barrier mechanisms of the blood-brain barrier and the blood-CSF barrier are important as they provide the necessary stable ionic environment for the brain. Studies by Davson showed that the ionic composition of CSF could only be accounted for by a secretory process [5]. The active transfer of some ions across the CSF-blood barrier as well as the blood-brain barrier creates an ionic environment in which the concentration of several major ions in CSF is markedly different, but also accounts for the fact that CSF and brain extracellular fluid concentration is largely independent of substantial concentration changes in plasma [11]. CSF has an excess of chloride and magnesium ions but a lower potassium and bicarbonate ion concentration compared with the concentration of these ions in plasma filtrate. Quantitative studies of the movement of small substances between CSF and brain suggests that the concentration of ions in extracellular fluid of the brain should largely be the same as that in CSF. The precise assessment and identification of ionic elements in the CSF is important to neurological diagnosis, however, the accurate discussion of this topic is beyond the scope of this review. The function of CSF as a connective fluid that relates the blood and lymphatic system with the CNS in both directions, but provides barriers for larger molecules such as proteins make this fluid a particularly rich molecular pool of potential disease markers.

\subsection{Source of CSF proteins}

It was originally believed that CSF proteins mainly originate from the blood and that the CSF protein composition is similar to that of other connective tissues, such as lymph or blood. However, there are clear differences in protein concentration and composition between blood plasma and CSF. The total protein concentration in CSF is about 200 times lower than that in the blood plasma. The pattern of their relative concentrations is very different in CSF compared to plasma. Nevertheless, the largest protein fractions in CSF originate from blood. Blood proteins enter into CSF at the choroid plexus and along its way between ventricles and SAS, increasing by about 2.5 fold in total protein concentration between the ventricular and lumbar
CSF. The constantly increasing concentration of serum proteins along the neuroaxis supports a diffusion-based mechanism for the transfer of proteins from serum into CSF. Protein transfer from the brain into CSF and from blood into CSF follows the laws of diffusion as a function of molecular size. In general, for small proteins, the barrier function is therefore less than for larger molecules. The diffusion-related transfer of proteins into the CSF compartment is the cause for molecular size-dependent selectivity of the barrier function. The time for serum proteins to equilibrate between blood and CSF is dependent on the blood-CSF concentration gradient and the molecular size of the protein. In fact, a correlation between the Stokes radius of the plasma proteins and the ratios of their concentrations in blood plasma to those in CSF is observed, clearly reflecting the diffusion-based mechanism of the CSF-blood barrier (data not shown). Under non-pathological conditions the time for diffusion of serum albumin protein from plasma into CSF is about one day whereas for IgM is several days. The diffusion controlled transfer of proteins from serum into CSF represents the actual blood-CSF barrier function.

The relative enrichment of some proteins in CSF, in particular Transthyretin and Cystatin $\mathrm{C}$ is not explained on the basis of a diffusion-based mechanism in which the proteins originate from the plasma and enter the CSF via the blood-CSF barrier. However, relative large amounts of those proteins are found in the choroid plexus, the source of most of the CSF. The origin of those proteins can be found within the epithelial cells of the choroid plexus. The intracellular presence of those proteins was verified by existence of their mRNA, providing an unambiguous proof of the expression of the corresponding gene within the choroid plexus [12]. Similarly, beta-2 microglobulin, ceruloplasmin, and beta A4 amyloid precursor protein and a number of other proteins known were also found to be expressed highly in choroid plexus and secreted towards the CSF [13]. The regulation of intracerebral synthesis of those proteins is not very well understood, but indicates an important functional role within the CNS. Of all the proteins know to be expressed in the choroid plexes, the role of transthyretin and its regulation is best understood. The intracerebral expression of this protein is conserved across a large number of species and the pattern of protein gene expression in the developing choroid plexus is related to the speed of functional maturation of the brain [14]. Much less is known and understood about the other proteins in the CSF that come from and are highly expressed in 
cells surrounding the CSF. This lack of new findings on the role and regulation of intracerbral expression of proteins in the current literature is a major driving force for the application of novel protein profiling methods in CSF analysis.

\subsection{CSF total protein concentration}

The detection of disease-related changes in the brain is the basic target of CSF protein analysis. Increased concentration of the CSF total protein was recognized as an indicator of neurological disease soon after the introduction of lumbar puncture. Many different analytical methods have been employed in the past to determine the mean protein concentration range in CSF and it is not surprising that a wide variety of mean values have been reported. A concentration between 150 and $500 \mathrm{mg} / \mathrm{L}$ of CSF is in general assumed to be normal for healthy adults. However, the concentration of proteins can fluctuate between $100 \mu \mathrm{g}$ and several $\mathrm{mg} / \mathrm{L}$ depending on age, health and a number of other factors that are discussed below.

Many neurological diseases are accompanied by an increased total protein concentration in cerebrospinal fluid, usually described in literature as a blood/CSF barrier dysfunction. Together with the increased concentration of CSF proteins a change in ratios between single proteins, e.g., IgG and albumin is generally observed. Since albumin is exclusively synthesized in the liver, a change in albumin concentration was interpreted as in increase in blood-CSF barrier permeability accompanied by a decline of selectivity for protein molecules of different size. The quantification of blood CSF barrier function by measurement of CSF/serum quotients was the theoretical basis for the clinical application of CSF proteins in diagnosis of CNS diseases for many years. However, the collection of quotient data from a large number of patients and the application of a diffusion-based mechanistic model to the measurement of plasma proteins in CSF allowed Reiber and coworkers [14] recently to develop a model that replaces the blood-CSF protein leakage model with a non-linear dynamics model of molecular flux for blood proteins. The model implies that a decrease in CSF bulk flow rate with a subsequent increase in tissue protein concentration and increasing net flux of blood molecules into the CSF is sufficient to explain the CSF protein data indicative of blood/CSF barrier dysfunction. The exclusive increase in plasma protein concentration in CSF and the decreased CSF flow influences the net molecular flux of proteins into the SAS resulting in an apparent non-linear function of the blood-CSF barrier for proteins of different size. This model allows the interpretation of many unexplained facts from the physiology of CSF and pathophysiology of neurological diseases and has led to a new approach for the quantification of the humoral immune response in CNS diseases [14, $15]$.

In contrast to earlier assumptions in which CSF was presumed to be a protein-free ultrafiltrate of plasma, the compositional differences of CSF to plasma allow CSF to function as a specialized connective tissue communicating effects between the brain and the CNS. In contrast to small molecules, macromolecules including proteins are not freely moving from the blood into the CSF via the choroidal epithelium boundary. Protein compositional studies of CSF, therefore, have a particular importance in the study of disease markers. The detection of intrathecally synthesized immunoglobulin fractions in CSF has been providing basic information about the state of the CNS for the past 100 years and the apparent non-linear nature of the barrier function has long been incorrectly interpreted as a leakage of the blood-CSF barrier. Proteins that originate within the brain and exchange into the CSF are subject to similar diffusion-based restrictions, making the detection of brain derived-disease markers dependent on the largely unknown nature and dynamics of the brain-CSF barrier.

\subsection{Dynamics of CSF molecular composition}

Determining the molecular composition of CSF at one point in time is equivalent to taking a snapshot of the health state of the CNS. Systematic study of disease mechanisms and markers of CSF require the longitudinal study of well characterized individuals. The interpretation of time-resolved data with a systematic approach is ultimately required to reduce the likelihood of simply measuring and interpreting natural changes in the brain and CSF that are unrelated to any specific disease, but reflect the natural fluctuation of the individual phenotype. The analysis of CSF proteins, more specifically, the intrathecal synthesis of Ig proteins in CSF together with CSF turnover is recognized today as a helpful tool for the differential diagnosis of neurological diseases. As discussed above, the change in CSF flow rate which modulates the protein concentration in CSF has a substantial influence in determining brain-derived from blood-derived protein fractions. It can be expected that protein concentrations synthesized locally or derived from brain through the exchange between ECF and CSF are similarly affected 
by CSF turnover. Of particular concern in CSF protein discovery and quantitative CSF protein measurements, therefore, are all factors that affect the CSF turnover, ultimately determining the dynamics of CSF molecular composition, in particular, for longitudinal studies.

\subsection{CSF formation}

It is apparent that estimates of CSF secretion in humans are technically very difficult, which may contribute to the large range of secretion rates estimated and reported in the literature for young, healthy adults, where CSF secretion from CP should be comparable. However, studies using imaging techniques and carefully conducted intracranial measurements established a rate of CSF formation around $0.34+/-$ $0.13 \mathrm{~mL} / \mathrm{min}$ [16]. It is thus replaced several times each day and good source for temporal information providing a readily accessible window into the health state of the CNS. The total volume of the fluid at any one time probably varies between $150-270 \mathrm{~mL}$ in different subjects with more than $75 \%$ of it outside the ventricles [17]. Welch concluded from a critical review of the literature that choroidal fluid formation involves two distinct processes that occur in series. First, the filtration across the choroidal capillary wall, and second, secretion by the choroidal epithelium [18]. Any process that interferes with filtration or active CSF secretion will affect CSF formation.

It has been shown that the rate of sodium exchange directly parallels the rate of choroidal fluid secretion and it is, therefore, believed to be dependent on the active transport of sodium via the sodium pump at the apical surface as well as at the intercellular clefts of the choroidal epithelium of the blood-CSF barrier [5, 19]. Conversely, the inhibitory effects of sodiumpotassium activated ATPase on choroidal CSF secretion by ouabain, cardiac glycosides and other sodium pump inhibitors have been described. The asymmetrical distribution of ion transporters and ion channels between the apical and the basolateral side of the CP epithelial membrane strongly supports a highly regulated mechanism of active fluid secretion in CP cells that provide a constant ionic composition of CSF [17]. In summary, one can conclude that the relative constancy of the rate of CSF formation corresponds to the relative constancy of CSF ionic composition.

A number of other factors that influence the rate of CSF formation have been investigated, such as the persistent elevation of intraventricular pressure which has been shown to reduce CSF formation [18]. It is also know that the circadian rhythm has an effect on CSF secretion rate, varying from $\sim 0.34 \mathrm{~mL} / \mathrm{min}$ in the afternoon to $\sim 0.61 \mathrm{~mL} / \mathrm{min}$ at night for healthy individuals [20]. The rate of CSF formation has also been shown to be reduced in aging individuals with a decline in overall secretion rate. A decreased CSF formation would be consistent with the accumulated changes during ageing in choroid plexuses tissue. Morphological changes in $\mathrm{CP}$ during aging have been reported and are significantly increased in age-related diseases, such as Alzheimer's disease [21]. Those age-related morphological changes also appear to be accompanied by changes in molecular composition of the CSF, affecting energy production and oxidative stress. In addition to age associated changes in CSF composition, age related changes in CSF turnover have been shown to originate from the concomitant increase in CSF volume and the reduced bulk flow and drainage into the venous system [21]. Cross sectional studies on healthy humans have revealed that moderate brain tissue atrophy occurs during normal aging leading to an almost doubling of the CSF volume.

\subsection{CSF absorption}

The rate of CSF absorption from the SAS into the venous blood through arachnoid villi and granulations has to be a multiple of its formation and its turnover, with a daily production of $\sim 500 \mathrm{~mL}$ CSF in a healthy individual. Recent measurements have shown that almost $\sim 40 \%$ of secreted CSF is returned to the circulation through spinal absorption at a mean rate of $\sim 0.17 \mathrm{~mL} / \mathrm{min}$. Spinal CSF absorption rate was twice as high in active individuals when compared to resting individuals caused by the increased hydrostatic pressure of the individuals in upright position when compared to a resting individual and increased CSF drainage through extracranial lymphatics [22].

\subsection{CSF turnover}

The reduced CSF outflow by systemic changes, such as increased venous pressure in vascular diseases that opposes CSF drainage into the venous system, changes in CSF absorption, and changes in the CSF total volume contribute to an overall decrease in CSF turnover and a considerable increase in CSF replacement time. Variations in CSF secretion and absorption are also affecting the movement of bulk CSF flow in SAS. As a result of cardiac cycle-related brain motions, CSF is transported and mixed through a constant bidirectional 
movement of CSF within the spinal SAS, enhancing diffusion-based mixing of CSF. Reduced CSF turnover and anomalous CSF mixing caused by the changed hydrodynamic variables of CSF production, movement and uptake add to the complexity of CSF protein measurements.

Collectively, the reduced CSF turnover affects the removal of any substance from CSF, which relies on bulk flow and drainage of fluid, such as proteins and other large molecules. However, large molecules, such as proteins will be proportionally more affected by changes in CSF system dynamics than smaller molecules. In fact, the reduced ability to clear proteins from CSF in humans as observed by elevated $\mathrm{CSF} /$ plasma ratios of albumin, IgG and macroglobulin in aging individuals has been described, but has been interpreted as a result of blood-brain barrier breakdown. Those observations that are now viewed as a result of reduced turnover of CSF and are consistent with the observation that large molecules accumulate in CSF with age [23]. For compositional studies in CSF tissue that are targeted towards finding low abundance proteins or disease markers, compositional measurements have to consider CSF turnover of the individual patient to account for the individual CSF clearance rates into the venous system of the body. Reduced turnover will most likely affect the accessibility of interesting proteins and make discovery of low abundance proteins more challenging. For example, disease marker discovery efforts from CSF in ageing individuals that in general exhibit increased CSF volumes and reduced turnover obscure any low-abundant leakage proteins indicative of molecular changes in the brain and may turn out to make measurements of significant molecules much more challenging. On the other hand, generally increased protein concentrations in CSF as a result of reduced turnover could be beneficial for the detection of low-abundant tissue leakage products, a group of protein products commonly believed to be the source of disease specific markers.

\subsection{CSF protein analysis and profiling}

Against the backdrop of a complex, yet fascinating physiology of CSF and its molecular components, it appears to be useful to look at the current knowledge and state of protein analysis in CSF. Survey of the current literature on this topic reveals a surprising discrepancy between the traditional, clinically focused and quantitative protein measurements and the more recent, largely qualitative efforts of analytical neurobiologists using a number of new protein profiling methods.

\subsection{CSF Protein analysis by electrophoretic methods}

The use of analytical separation tools to look at the CSF protein content is parallel with developments in the separation sciences. The first analysis of CSF proteins emerged with the separation and analysis of its most abundant protein components using electrophoretic separation techniques in paper. CSF protein composition then was described as a series of bands representing prealbumin, albumin, alpha 1 globulin, alpha 2 globulin, beta globulin and gamma globulin fractions. This type of analysis dominated the separation analysis side of CSF protein work for many decades until recently, when a series of one and two dimensional electrophoretic separation techniques were used to elucidate the molecular composition of CSF. CSF proteins were separated into more than 40 distinct bands and visualized using immunoelectrofocusing methods [24]. These protein patterns have been found to be of diagnostic interest and were used to investigate CSF protein abnormalities in a number of neurological diseases [25, 26]. Soon after the introduction of high resolution two-dimensional electrophoresis (2-DE) in 1975 by Klose [27] the first 2-DE map of the CSF proteome was published [28]. The composite map of CSF proteins, constructed from the analysis of the electrophoretic pattern from the same CSF sample revealed more than 300 individual proteins in this single CSF sample. Many protein spots were clustered revealing an abundance of minor charge differences in CSF proteins originating from posttranslational modifications. In the absence of mass spectrometry techniques for the unambiguous identification of proteins, the CSF patterns were identified by a combination of co-electrophoresis of purified proteins, glycoprotein stain and positional analysis of existing 2DE maps from serum. Differential analysis of CSF and diluted plasma gel patterns more than 25 years ago already established the presence of CSF specific proteins in 2-DE maps. However, they could not be identified at that time.

Equipped with the ability to separate hundreds of protein species from several hundred microliters of CSF many research groups have used the 2-DE technique to investigate differentially expressed CSF proteins in neurological diseases [29-31]. The challenge in those studies is the ability to reproducibly generate a $2-\mathrm{DE}$ map that allows the matching of gel patterns within a patient group and between patient groups [32-34]. Since the publication of the first 2-DE maps of CSF proteins, improvements in protein spot detection and 


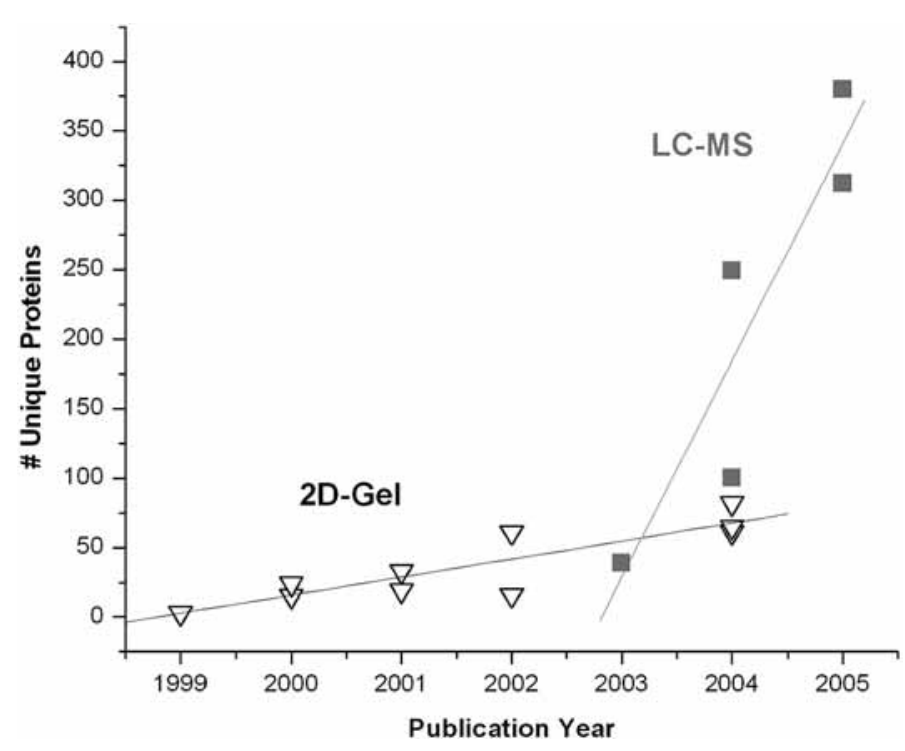

Fig. 1. Shows the dramatic increase in number of unique CSF proteins described in publications in the past 6 years. Triangles indicate the number of published protein identifications investigated with gel-based approaches [113,114,116,117,119,121,123,124,126,131]. Squares indicate the number of published protein identifications determined by LC-based methods [39-41,115,118].

identification technologies have increased the number of proteins spots that can be visualized in a 2-DE map and the reproducibility of 2-DE based differential display techniques. Most of the advances in CSF protein analysis, however, arise from the application of mass spectrometry to the identification and characterization of protein spots. The number of protein spots separated and identified by 2-DE gel separation techniques and identification by mass spectrometry today is usually about twice that of the first 2-DE map [35]. Despite the impr ovements in detection sensitivity provided by enhanced gel staining techniques, better sample preparation strategies and increased sensitivity of mass spectrometers for proteins recovered from gel spots, the total number of unique proteins analyzed and quantified has not substantially exceeded 40 proteins (Fig. 1).

However, the practical utility of 2-DE studies of high-abundance proteins has been substantial. The separation by charge and protein size reveals even the smallest changes in proteins and allows the differential analysis of highly abundant proteins in CSF from disease and non-diseased individuals. Investigations of several neurological diseases have revealed a number of complex combinations of post-translational modifications of CSF proteins that can be discriminated by 2DE methods and are potentially useful to examine disease processes $[4,32,36]$. However, the complexity and effort in producing and characterizing 2-DE patterns has made it very difficult to conduct larger scale clinical studies to elucidate disease markers for neurological diseases in CSF.

\subsection{CSF protein analysis by antibody-based techniques}

In an attempt to survey the currently known proteins in CSF, we reviewed the published literature on CSF protein measurements through Pubmed. Of particular interest were CSF protein measurements that established clinical reference values with a validated diagnostic assay for a particular protein known to be present in CSF. The search results show that 47 proteins have been analyzed in CSF by validated clinical assays as of today (Table 1). It is probably not surprising that most of the proteins determined were using antibodybased assays originally developed for plasma protein measurements, with a few exceptions $[37,38,79]$. It is therefore difficult to assess whether those protein measurements included also brain specific protein variants that exhibit epitopes different from plasma-derived proteins. It is noteworthy that the list of proteins analyzed contains very few plasma-derived proteins, but mainly proteins that are believed to be brain-derived or intrathecally synthesized. The reference intervals reported in those measurements are plotted in Fig. 2 and span 9 orders of magnitude in concentration comparing the most abundant CSF protein serum albumin with the level of 14-3-3 protein detected at $\mathrm{pg} / \mathrm{L}$ in 


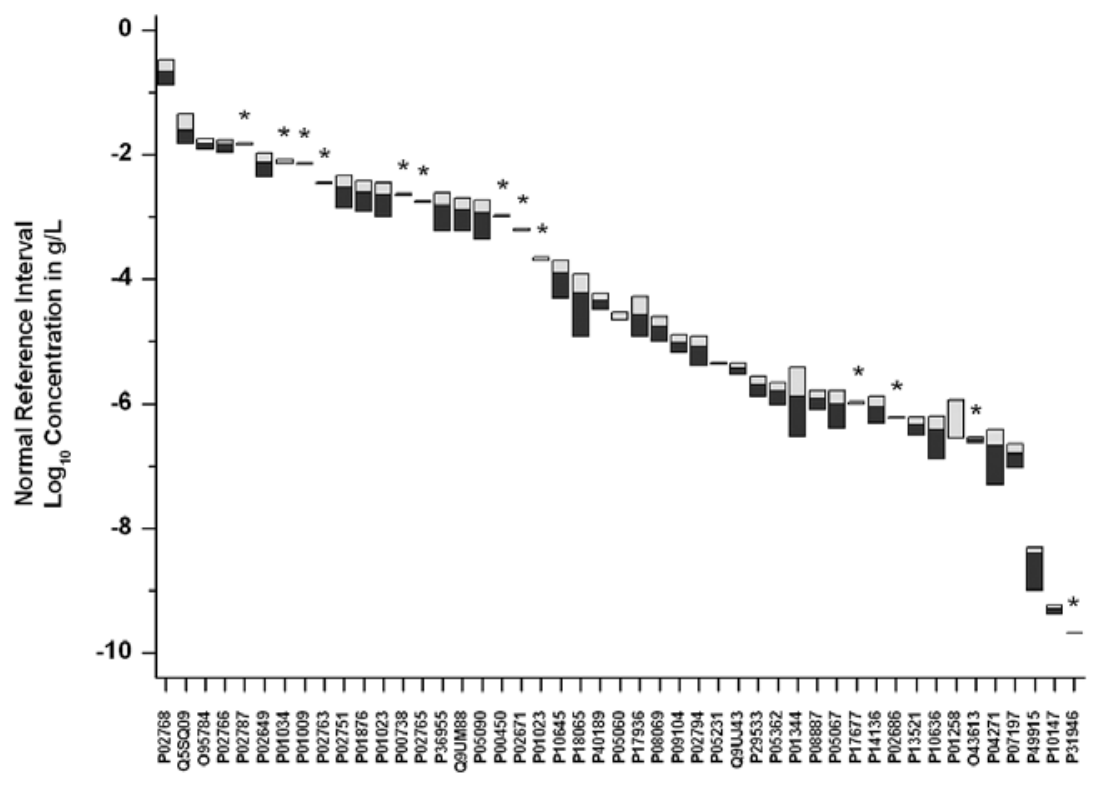

Uniprot ID for Protein Analytes in Human Cerebospinal Fluid

Fig. 2. Shows reference intervals for 49 protein analytes in human cerebrospinal fluid. The abundance for the normal reference intervals is plotted on a $\log _{10}$ scale spanning 9 orders of magnitude. Analytes that only had median values, but no lower and higher limits reported are marked with a star (*). Names for the protein analytes and literature referenced are shown in Table 1.

CSF. However, protein reference values determined in those quantitative CSF protein measurements have to be carefully interpreted given the fact that CSF tissue is highly dynamic in its composition and the absolute concentration of proteins is a factor of many variables. The determination of absolute concentration of bloodderived CSF proteins is modulated by a number of factors; the CSF bulk low rate, the individual serum concentration and the individual diffusion pathway across the CSF-blood barrier, the age of the individual, the site of puncture and the volume of CSF extraction. Similarly, the absolute concentration of brain-derived proteins is modulated by the total CSF volume, and the individual diffusion pathway from the site of origin to the CSF, the age of the individual, the site of puncture and the volume of CSF extraction. Although, clinical studies in patients typically control factors such as age of patient, site of puncture and CSF volume extraction, protein concentrations changes due to the extraordinary dynamics of CSF tissue as briefly discussed above is rarely accounted for in those investigations. Very few publications report protein reference values together with CSF/plasma albumin ratios that could help in correcting for variations in CSF volume and CSF turnover.

Most of the clinically-focused CSF protein work that we reviewed focused on studying the potential of those proteins as a disease marker for neurological diseases (Table 2). In some investigations proteins were analyzed as a potential disease marker for more than one clinical indication. Combinations of proteins were also investigated as potential disease marker panels. The overrepresentation of neurodegenerative diseases, such as Alzheimer's disease, Creutzfeldt-Jakob disease and Multiple-Sclerosis is not surprising, but is evidence to the importance of protein CSF measurements for the diagnosis and study of common neurological diseases.

\subsection{New strategies for protein analysis in CSF}

The review of the literature and summary of the known protein components of the CSF and their determined reference intervals provides a good estimate of the dynamic range of the CSF proteins and the requirements for comprehensive protein measurements in CSF. Blood-derived serum albumin at a concentration range of $130-350 \mathrm{mg} / \mathrm{L}$ presents the upper concentration level for CSF proteins, while the lowest detectable amount of protein using antibody-based detection techniques is described in the literature at $4-6 \mathrm{pg} / \mathrm{L}$ for the 14-3-3 protein. It is significant to recognize that these protein measures in CSF have covered already a concentration range of $8-10$ orders of magnitude. At this 
Table 1

Proteins and their UniProt ID with references for protein analytes listed in Fig. 1. References values for protein entries that show no literature reference were provided by a commercial reference laboratory

\begin{tabular}{|c|c|c|}
\hline UniProt ID & Protein & Reference \\
\hline P02768 & Human Albumin Precursor & [14] \\
\hline Q5SQ09 & Prostaglandin D2 synthase $21 \mathrm{kDa}$ & [57] \\
\hline O95784 & IgG Fc binding protein & [14] \\
\hline P02766 & Transthyretin precursor (Prealbumin) & [14] \\
\hline P02787 & Serotransferrin, Transferrin, Siderophilin & [23] \\
\hline P02649 & Apolipoprotein E Precursor & [58] \\
\hline P01034 & Cystatin C (Neuroendocrine Basic Protein) & {$[14]$} \\
\hline P01009 & Alpha-1-antitrypsin precursor & [14] \\
\hline $\mathrm{P} 02763$ & Alpha-1-acid glycoprotein 1 precursor (AGP 1) (Orosomucoid 1) & {$[14]$} \\
\hline $\mathrm{P} 02751$ & Fibronectin Precursor & [59] \\
\hline P01876 & Ig alpha- 1 chain $\mathrm{C}$ region & [60] \\
\hline P01023 & Alpha-2-Macroglobulin Precursos(Alpha-2-M) & [60] \\
\hline P00738 & Haptoglobulin-2 Precursor & [14] \\
\hline $\mathrm{P} 02765$ & Alpha-2-HS-glycoprotein, Fetuin-A & [14] \\
\hline P36955 & Pigment epithelium-derived factor & [61] \\
\hline Q9UM88 & Beta 2-microglobulin protein & [62] \\
\hline P05090 & Apolipoprotein D & [63] \\
\hline P00450 & Ceruloplasmin Precursor (Ferroxidase) & [23] \\
\hline P02671 & Fibrinogen Alpha, Alpha-E Chain Precursors & [23] \\
\hline P01023 & Alpha-2-Macroglobulin Precursor (Alpha-2-M) & {$[60]$} \\
\hline P10645 & Chromogranin A Prescursor, Parathyroid secretory protein 1 & {$[64]$} \\
\hline P18065 & Insulin-like growth factor binding protein 2, IGFBP-2 & [65] \\
\hline P40189 & sIL-6Receptor beta & [66] \\
\hline P05060 & Secretogranin-1 precursor (Secretogranin I) (SgI) (Chromogranin B) & [67] \\
\hline P17936 & Insulin-like growth factor binding protein 3, IGFBP-3 & [68] \\
\hline P08069 & Insulin-like growth factor I receptor precursor & [68] \\
\hline P09104 & Gamma enolase,Neurospecific enolase,NSE, -phospho-D-glycerate hydro-lyase, Enolase-2 & [69] \\
\hline P02794 & Ferritin heavy chain, Ferritin H subunit & [70] \\
\hline P05231 & IL-6 & [66] \\
\hline Q9UJ43 & soluble L-selectin (Lymphocyte adhesion molecule 1) & [71] \\
\hline P29533 & Soluble Adhesion Molecules (sVCAM-1) & [71] \\
\hline P05362 & intrathecal soluble adhesion molecules(sICAM-1) & [71] \\
\hline $\mathrm{P} 01344$ & Insulin-like growth factor II precursor (IGF-II) (Somatomedin A) & [68] \\
\hline P08887 & sIL-6Receptor alpha & [66] \\
\hline P05067 & Amyloid beta A4 protein Precursor,beta Amyloid & [72] \\
\hline P17677 & Neuromodulin, Axonal membrane protein GAP-43, Neural phosphoprotein B-50 & - \\
\hline P14136 & Glial Fibrillary Acidic Protein (Alpha albumin) & [73] \\
\hline P02686 & Myelin Basic Protein (MBP) & [14] \\
\hline P13521 & Secretogranin-2 precursor (Secretogranin II) (SgII) (Chromogranin C) & {$[67]$} \\
\hline P10636 & Microtubule-associated protein tau, Neurofibrillary tangle protein & [74] \\
\hline P01258 & Calcitonin (Thyrocalcitonin), Calcitonin & - \\
\hline O43613 & Hypocretin-1 (Orexin-A) & [75] \\
\hline P04271 & S-100 protein, beta chain & [76] \\
\hline P07197 & Neurofilament triplet M protein (160 kDa neurofilament protein), Neurofilament medium polypeptide & [38] \\
\hline P49915 & Glutamine Synthase & [77] \\
\hline P10147 & chemokine macrophage inflammatory protein-1- $\alpha$, MIP- $\alpha$, macrophage inflammatory protein 1-alpha & [78] \\
\hline P31946 & 14-3-3 Protein (Protein kinase $\mathrm{C}$ inhibitor protein 1 ) & [79] \\
\hline
\end{tabular}

point it is a matter of pure speculation to assess the relevant depth of the CSF protein contents and its entire dynamic range of protein concentrations. The existence and the results of all currently available CSF protein measurements indicate that knowing the exact dynamic range of the CSF protein composition is probably at this point not very significant for disease marker discovery, since measurements at any concentration range have shown to be clinically meaningful. Whether CSF protein measurements for disease marker discovery at a much lower level are more relevant can be a matter of significant division of opinion. However, it is clear at this point that detection of very low levels of proteins in CSF and simultaneous detection of all isoforms of those proteins is very challenging. Given the fact that the 40 most abundant proteins in CSF give rise to more than 600 different protein species, but only cover 3 orders of magnitude in concentration range, it is sober- 
Table 2

CSF proteins that were studied as potential disease markers for neurological diseases. Some proteins were investigated as disease markers for more than one clinical indication. Combinations of proteins as potential disease marker panels were also investigated, but are not indicated in this summary

\begin{tabular}{|c|c|c|}
\hline Protein & Disease & Reference \\
\hline 14-3-3 protein & CJD & [79] \\
\hline Acetylcholinesterase & Alzheimer's disease & {$[80]$} \\
\hline Amyloid protein precursor (APPs) & Alzheimer's disease;Depression, & {$[81][82][83]$} \\
\hline Apolipoprotein D & Alzheimer's disease,Traumatic brain injury & {$[63][84]$} \\
\hline Apolipoprotein E & Alzheimer's disease & {$[85 ; 86]$} \\
\hline $\mathrm{A} \beta 42(\mathrm{~A} \beta 40 / \mathrm{A} \beta 42)$ & CJD, Alzheimer's disease, & [87] \\
\hline $\begin{array}{l}\text { Brain-type isozyme of creatine kinase (CK- } \\
\text { BB), }\end{array}$ & CJD & {$[88]$} \\
\hline $\begin{array}{l}\text { Chemokine macrophage inflammatory } \\
\text { protein- } \alpha \text { (MIP- } \alpha)\end{array}$ & Schizophrenia, Guillain-Barre syndrome (GBS), & {$[89][78]$} \\
\hline Cystatin C & Alzheimer & {$[90]$} \\
\hline $\begin{array}{l}\text { Acyl-CoA-binding protein (ACBP) } \\
\text { (Diazepam binding inhibitor) (DBI) }\end{array}$ & Alzheimer's disease,Parkinson's Disease, & [91] \\
\hline Dopamine-releasing protein & Lower back pain & {$[92]$} \\
\hline Ferritin & brain haemorrhage, necrosis & {$[70]$} \\
\hline Glutamine Synthase & Alzheimer's disease & [77] \\
\hline H-FABP (Human fatty acid binding protein) & CJD & {$[90]$} \\
\hline Hypocretin-1 (Orexin-A) & narcolepsy & {$[75]$} \\
\hline $\operatorname{IgG}, \operatorname{Ig} \mathrm{A}, \operatorname{IgM}$ & Multiple sclerosis & [93] \\
\hline IL-6 soluble receptor & Alzheimer's disease/stroke & [94] \\
\hline Insulin-like growth factor binding protein-2 & Central nervous system tumours & {$[65]$} \\
\hline Insulin-like growth factor binding protein-3 & Central nervous system tumours & {$[68]$} \\
\hline Interleukin-1 receptor type & Alzheimer's disease & [95] \\
\hline $\begin{array}{l}\text { Intrathecal soluble adhesion } \\
\text { molecules(sICAM-1) }\end{array}$ & MS & {$[71]$} \\
\hline Myelin basis protein (MBP) & Multiple sclerosis & {$[93 ; 96]$} \\
\hline Neurofilament proteins & $\begin{array}{l}\text { Multiple sclerosis; MS optic neuritis,supranuclear palsy,Multiple- } \\
\text { system atrophy, }\end{array}$ & {$[38]$} \\
\hline Neurospecific enolase (NSE) & Creutzfeld-Jakob disease/spongiform Encephalopathies & {$[69][97]$} \\
\hline Pigment epithelium-derived factor & ALS & [98] \\
\hline $\begin{array}{l}\text { Prostaglandin B synthase } \\
\text { (Beta-trace protein) }\end{array}$ & $\begin{array}{l}\text { Spinal canal stenosis; bacterial meningitis, Carbohydrate-deficient } \\
\text { glycoprotein syndromes, }\end{array}$ & {$[36 ; 99 ; 100]$} \\
\hline S-100 protein & CJD, Spinal cord ischemia & {$[101][79][102]$} \\
\hline S-100B protein & optic neuritis & {$[103][104]$} \\
\hline Soluble Adhesion Molecules (sVCAM-1) & MS & [71] \\
\hline Soluble L-selectin & MS,systemic lupus erythematosus & [71] \\
\hline Somatostatin & $\mathrm{AD} /$ depression & {$[105]$} \\
\hline$\beta-2$ transferrin, desialated transferrin & Alzheimer's disease & {$[106][74][107-109]$} \\
\hline$\beta$-Endorphin & Infantile autism, Rett syndrome, & {$[110]$} \\
\hline Synaptotagmin & Alzheimer's disease & {$[111]$} \\
\hline Total Tau & $\begin{array}{l}\text { CJD, Alzheimer's disease, Alcohol-induced organic brain disorders, } \\
\text { Frontal lobe dementia, Corticobasal degeneration, }\end{array}$ & [112] \\
\hline Transthyretin & Alzheimer's disease & {$[86]$} \\
\hline
\end{tabular}

ing to recognize that current $2 \mathrm{D}$-gel based separation techniques most likely have only uncovered the "tip of the iceberg" of CSF proteins, some of which could be considered potential protein disease markers.

\subsection{Gel-free protein analysis}

Despite the separation power of 2D-gel protein analysis techniques, the large dynamic range of the CSF proteins and the large number of proteins present in CSF represents an insurmountable challenge to gel- based analysis methods and limits its application to the study of CSF protein composition of the most abundant protein molecules. The number of CSF proteins has slightly increased in the recent past with the introduction of new affinity depletion techniques that remove the most abundant proteins before the separation analysis and allow the detection and quantification of more low abundance proteins. A review of the literature on CSF proteins recently analyzed by $2 \mathrm{D}$-gel techniques indicate that approximately 60 proteins have been described from CSF with the introduction of depletion 
techniques Fig. 1. Although in many of these studies the goal was not to detect as many proteins as possible, the graph indicates that application of conventional 2-DE methods limit the discovery of CSF proteins to high abundant proteins. It is noteworthy that in most 2DE-based or IEF-based studies the goal of the investigation was not the profiling of CSF proteins, but the work was focused towards the investigation of particular proteins and their isoforms. Even though the dynamic protein composition of CSF largely precludes a well-defined endpoint similar to the identification of all genes in a static genome, a full compositional profiling of all CSF proteins renders any analysis technique ineffective. However, the 2D-gel based studies have been vital in establishing the technological hurdles faced by alternative approaches and have provided an excellent test-bed for the exploration of new methodological approaches.

Largely due to the fact that 2D electrophoresis techniques have a low dynamic range $\left(\sim 10^{4}\right)$ for analyzing complex biological samples, which usually contain proteins and peptides in a concentration range of 10 to 12 orders of magnitude, more recent work in compositional profiling CSF proteins has focused on gel-free, liquid chromatography-mass spectrometry (LC-MS) based analysis techniques. The ability of those analysis techniques to separate several hundred micrograms of digested protein mixtures and identify those peptides automatically using database search algorithms has led to the interest of using those methods to identify and quantify large numbers of CSF proteins. LC-based sample separation methods coupled directly to tandem mass spectrometry allow the separation and analysis of complex mixtures with a dynamic range between $10^{5}-10^{7}$. The application of a variety of LC-MS based techniques for the identification and differential quantification in neuroscience was recently reviewed [3] and the most prolific work with respect to CSF protein compositional profiling was reported in work that employed LC-MS ion trap mass spectrometry [39-41]. Review of those reports indicates that the application of LC-MS based techniques for CSF protein profiling has dramatically increased the number of proteins detected in human CSF Fig. 1. Review of all CSF protein profiling reports that utilize conventional 2-DE methods or gel-free LC/MS approaches reveals that a number of proteins previously undetected in human CSF were reported by several investigators (Table 3). From the wealth of the reported data, the table only lists those proteins that were found in at least two independent experiments. In particular reports by in- vestigators that employed gel-free LC/MS techniques contributed to this list a number of new proteins that are thought to be brain derived, e.g., Glial Fibrillary Acidic Protein, Neural Cell Adhesion Molecule 2 Precursor. It should be noted that many more proteins were reported in the reviewed literature, but many of those proteins could not be confirmed by other references. In some reports enrichment techniques were used to allow the detection of low-abundance, synaptosomal proteins, such as synaptotagmin [42]. The protein summary shown in Table 3 brings the number of CSF proteins reported in the literature to well over 100 unique proteins.

Moreover, well over 300 unique proteins were reported in two of these analyses of human CSF [40, 41]. In two of these reports the dynamic range of the compositional profiling analysis was increased by the application of selective affinity purification methods, e.g., ICAT-labeling and purification of CSF proteins and fractionation of the CSF protein contents by lectin chromatography into a deglycosylation protein fraction and a glycoprotein enriched protein fraction. These experiments increased the number of proteins previously identified from 165 proteins to over 320 proteins [40] and in one report to several hundred proteins [41]. In the experiments described by Zhang et al. and Hühmer et al. the resulting ion trap MS/MS spectra were searched against the human protein index matching the experimental MS/MS spectra not only to peptide sequences of known CSF proteins, but also identifying a number of peptides of splice isoforms of known proteins and, more significantly, established the presence of a large number of previously unknown gene transcripts in CSF, generally referred to as hypothetical proteins. Zhang reported the detection of 315 proteins in young healthy adults. Out of the 315 reported proteins, 106 proteins were identified to match theoretical open reading frames in the human genome. In addition to the 106 hypothetical proteins detected, many MS/MS spectra were matched to protein splice variants recorded in the human protein index sequence database. Hühmer reported the presence of several thousands peptides matching to roughly several hundred proteins in the database. Similarly to the report by Zhang, the protein listing showed over $30 \%$ of the proteins to be hypothetical proteins or gene transcripts of unknown function. In addition to the large number of hypothetical proteins, 111 splice variants were also identified [43].

The comparison of those two datasets, however, showed that there is a relatively poor fit between the proteins or gene transcripts described in those two reports. 
Table 3

List of commonly detected CSF proteins in CSF compositional studies. Proteins that were identified in at least two independent studies of human CSF with either gel-based analysis or gel-free LC/MS approaches are listed in this table

$\begin{array}{ll}\text { UniProt } & \text { PROTEINS } \\ \text { P01876 } & \text { IG ALPHA-1 CHAIN C REGION } \\ \text { P02023 } & \text { HEMOGLOBIN BETA CHAIN } \\ \text { P02760 } & \text { AMBP PROTEIN (ALPHA-1-MICROGLOBULIN) (INTER-ALPHA- } \\ & \text { TRYPSIN INHIBITOR LIGHT CHAIN) } \\ \text { P02649 } & \text { APOLIPOPROTEIN E PRECURSOR (APO-E) } \\ \text { P01008 } & \text { ANTITHROMBIN-III PRECURSOR (ATIII) } \\ \text { P01034 } & \text { CYSTATIN C PRECURSOR (NEUROENDOCRINE BASIC POLY } \\ & \text { PEPTIDE) (GAMMA-TRACE) } \\ \text { P00734 } & \text { PROTHROMBIN } \\ \text { P69905 } & \text { HEMOGLOBIN ALPHA CHAIN } \\ \text { P02774 } & \text { VITAMIN D-BINDING PROTEIN PRECURSOR (DBP) } \\ & \\ \text { P01834 } & \text { IG KAPPA CHAIN C REGION } \\ \text { P06396 } & \text { GELSOLIN PRECURSOR PLASMA } \\ \text { P02766 } & \text { TRANSTHYRETIN PRECURSOR (PREALBUMIN) (TBPA) (TTR) } \\ & \\ \text { P02749 } & \text { BETA-2-MICROGLOBULIN PRECURSOR } \\ \text { P36955 } & \text { PIGMENT EPITHELIUM-DERIVED FACTOR PRECURSOR } \\ \text { P01028 } & \text { COMPLEMENT C4 PRECURSOR (CONTAINS: C4A ANAPHY } \\ \text { P01857 } & \text { LATOX) } \\ \text { P02647 } & \text { APOLIPOPROTEIN A-I PRECURSOR (APO-AI) } \\ \text { SERUM ALBUMIN PRECURSOR } \\ \text { K05090 }\end{array}$

P04406 GLYCERALDEHYDE-3-PHOSPHATE DEHYDROGENASE, LIVER Q02383 SEMENOGELIN-2

P02675 FIBRINOGEN BETA CHAIN (PRECURSOR)

P25311 ZINC-ALPHA-2-GLYCOPROTEIN (PRESCURSOR)

P02671 FIBRINOGEN ALPHA/ALPHA-E CHAIN (PRECURSOR)

P01024 COMPLEMENT C3 PRECURSOR

P02753 PLASMA RETINOL-BINDING PROTEIN (PRECURSOR) (PRBP)

P01859 IG GAMMA-2 CHAIN C REGION

P01842 IG LAMBDA CHAIN C REGIONS

P00441 SUPEROXIDE DISMUTASE (CU-ZN)

O14791 APOLIPOPROTEIN L PRECURSOR (APO-L)

P02761 GLIAL FIBRILLARY ACIDIC PROTEIN, ASTROCYTE (GFAP)

P10909 CLUSTERIN PRECURSOR (COMPLEMENT-ASSOCIATED PROTEIN) (APOLIPOPROTEIN J)

P01023 ALPHA-2-MACROGLOBULIN (PRECURSOR) (ALPHA-2M)

P01009 ALPHA-1-ANTITRYPSIN PRECURSOR (ALPHA-1 PROTEASE

Reference

[113],[114],[115],[111]

[113],[114],[116],[117],[118],[41]

[113],[115]

[113],[119],[120],[116],[121],[90],[41]

[113],[119],[116],[115],[90],[41]

[113],[122],[119],[123],[116],[90],[115],[118],[41],

[117],[121],[39]

[113],[116],[90],[124]

[113],[116],[41]

[114],[113;113],[119],[123],[34],[116],[115],[90],

[118],[41]

[114],[113],[119],[123],[41]

[114],[113],[119],[116],[39],[125],[90],[118],[41]

[114],[113],[122],[119],[123],[116],[39],[117],

[121],[126],[115],[118],[41]

[114],[113],[122],[119],[123],[116],[39],[117],[90],

[118],[41]

[114],[113],[116],[90],[118],[41]

[114],[113],[116],[90],[39],[117],[115],[118],[41]

[114],[113],[116],[90],[119],[123],[117],[121],

[115],[41]

[114],[113],[116],[90],[41]

[114],[121],[41]

[114],[121],[41]

[114],[90],[122],[119],[116],[123],[39],[117],[121], [118],[41]

[114],[118]

[114],[124]

[114],[39],[41]

[114],[123],[116],[39],[121],[41]

[114],[115],[41]

[114],[119],[127],[116],[90],[39],[117],[118],[41]

[114],[119],[116],[117],[115],[118],[41]

[114],[119],[116],[41]

[114],[116],[121],[41]

[114],[116],[90],[41]

[114],[41]

[121],[115],[128]

[121],[116],[114],[90],[115],[41]

[90],[114],[39],[121],[115],[41]

[90],[114],[119],[123],[116],[118],[117],[121],[41] INHIBITOR)

P41222 PROSTAGLANDIN-H2 D-ISOMERASE PRECURSOR

P05067 ALZHEIMER'S DISEASE AMYLOID A4 PROTEIN PRECURSOR

P23142 FIBULIN-1 PRECURSOR

P01860 IG GAMMA-3 CHAIN C REGION

P05060 SECRETOGRANIN I PRECURSOR (SGI) (CHROMOGRANIN B)

Q9UBP4 DICKKOPF RELATED PROTEIN-3 PRECURSOR (DKK-3)

P02042 HEMOGLOBIN DELTA CHAIN

P01344 INSULIN-LIKE GROWTH FACTOR II PRECURSOR (IGF-II)

P06727 APOLIPOPROTEIN A-IV PRECURSOR (APO-AIV)

P00738 HAPTOGLOBIN-2 PRECURSOR

P01019 ANGIOTENSINOGEN PRECURSOR (CONTAINS: ANGIOTENSIN)

Q59FY4 ACETYL-COENZYME A CARBOXYLASE ALPHA ISOFORM 2 VARIANT

[90] [114] [119] [123] [34] [116] [39] [121] [126] [115] [128] [118] [41]

[90],[39],[121],[41]

[90],[39],[115],[41]

[90],[41]

[118],[121],[39],[41]

[118],[41]

[118],[41]

[118],[41]

[124],[114],[113],[116],[39],[121],[115],[118],[41]

[124],[114],[34],[116],[90],[117],[118],[41]

[124],[116],[39],[118],[41]

[39],[123] 
Table 3, continued

\begin{tabular}{|c|c|c|}
\hline UniProt & PROTEINS & Reference \\
\hline O43505 & N-ACETYLLACTOSAMINIDE & {$[39],[116],[114]$} \\
\hline & BETA-1,3-N-ACETYLGLUCOSAMINYLTRANSFERASE & \\
\hline Q12805 & $\begin{array}{l}\text { EGF-CONTAINING FIBULIN-LIKE EXTRACELLULAR MATRIX } \\
\text { PROTEIN } 1 \text { (FIBULIN-3) }\end{array}$ & {$[39],[116],[114],[124],[90]$} \\
\hline P10643 & COMPLEMENT COMPONENT C7 PRECURSOR & [39],[41] \\
\hline P04196 & HISTIDINE-RICH GLYCOPROTEIN PRECURSOR & [39],[41] \\
\hline Q9NQX5 & $\begin{array}{l}\text { NEURAL PROLIFERATION DIFFERENTIATION AND CONTROL } \\
\text { FACTOR }\end{array}$ & {$[39],[41]$} \\
\hline Q15818 & NEURONAL PENTRAXIN I PRECURSOR (NP-I) (NP1) & [39],[41] \\
\hline P10451 & OSTEOPONTIN PRECURSOR (BONE SIALOPROTEIN 1) & [39],[41] \\
\hline P49760 & PROTEIN KINASE CLK2 & [39],[41] \\
\hline P09486 & SPARC PRECURSOR & [39],[41] \\
\hline P02787 & $\begin{array}{l}\text { SEROTRANSFERRIN PRECURSOR (SIDEROPHILIN) (BETA-1- } \\
\text { METAL BINDING GLOBULIN) }\end{array}$ & $\begin{array}{l}{[123],[116],[90],[114],[118],[117],[119],[121],} \\
{[118],[115],[41]}\end{array}$ \\
\hline P02790 & HEMOPEXIN PRECURSOR (BETA-1B-GLYCOPROTEIN) & {$[123],[116],[90],[39],[121],[115],[41]$} \\
\hline P02765 & $\begin{array}{l}\text { ALPHA-2-HS-GLYCOPROTEIN PRECURSOR (FETUIN-A) (AL } \\
\text { PHA-2-Z-GLOBULIN) }\end{array}$ & {$[123],[116],[39],[115],[41]$} \\
\hline P60709 & ACTIN, CYTOPLASMIC 1 (BETA-ACTIN) & {$[115],[116],[90],[114]$} \\
\hline P02748 & COMPLEMENT COMPONENT C9 PRECURSOR & {$[115],[41]$} \\
\hline P19652 & ALPHA-1-ACID GLYCOPROTEIN 1 PRECURSOR (AGP 1) & {$[119],[123],[116],[39],[121],[115],[41]$} \\
\hline P02462 & COLLAGEN ALPHA 1(VI) CHAIN PRECURSOR & {$[119],[116],[121],[41]$} \\
\hline P05452 & TETRANECTIN PRECURSOR (TN) & {$[116],[114],[124],[41]$} \\
\hline P01871 & IG MU CHAIN C REGION & {$[116],[114],[115],[41]$} \\
\hline P02679 & FIBRINOGEN GAMMA CHAIN PRECURSOR & {$[116],[114],[41]$} \\
\hline P62988 & UBIQUITIN & {$[116],[121],[41]$} \\
\hline P01011 & ALPHA-1-ANTICHYMOTRYPSIN PRECURSOR (ACT) & {$[116],[90],[114],[39],[121],[115],[118],[41]$} \\
\hline P00450 & CERULOPLASMIN PRECURSOR (FERROXIDASE) & {$[116],[90],[114],[39],[121],[41]$} \\
\hline P00751 & COMPLEMENT FACTOR B PRECURSOR (C3/C5 CONVERTASE) & {$[116],[90],[117],[41]$} \\
\hline P02749 & BETA-2-GLYCOPROTEIN I PRECURSOR (APOLIPOPROTEIN H) & {$[116],[90],[124]$} \\
\hline P00747 & PLASMINOGEN PRECURSOR (CONTAINS: ANGIOSTATIN) & {$[116],[129],[39],[117],[121],[41]$} \\
\hline P04217 & ALPHA-1B-GLYCOPROTEIN & {$[116],[90],[39],[115],[41]$} \\
\hline P09871 & COMPLEMENT C1S COMPONENT PRECURSOR (C1 ESTERASE) & {$[116],[90],[39],[115],[41]$} \\
\hline P04004 & VITRONECTIN PRECURSOR (SERUM SPREADING FACTOR) & {$[116],[90],[39],[115],[41]$} \\
\hline P01597 & IG KAPPA CHAIN V-I REGION DEE & {$[116],[90],[41]$} \\
\hline Q06830 & PEROXIREDOXIN 1 (THIOREDOXIN PEROXIDASE 2) & {$[116],[128]$} \\
\hline P09211 & GLUTATHIONE S-TRANSFERASE P & {$[116],[128]$} \\
\hline P07339 & CATHEPSIN D PRECURSOR & {$[116],[128],[118],[41]$} \\
\hline P35542 & SERUM AMYLOID A-4 PROTEIN PRECURSOR & {$[116],[118],[41]$} \\
\hline P10645 & CHROMOGRANIN A PRECURSOR (CGA) & {$[116],[39],[121],[118],[41]$} \\
\hline P01777 & IG HEAVY CHAIN V-III REGION TEI & {$[116],[39],[121],[41]$} \\
\hline P02750 & LEUCINE-RICH ALPHA-2-GLYCOPROTEIN (LRG) & {$[116],[39],[115],[118],[41]$} \\
\hline P02751 & $\begin{array}{l}\text { FIBRONECTIN PRECURSOR (FN) } \\
\text { (COLD-INSOLUBLE GLOBULIN }\end{array}$ & {$[116],[39],[41]$} \\
\hline O15394 & NEURAL CELL ADHESION MOLECULE 2 PRECURSOR & [116],[39],[41] \\
\hline P02652 & APOLIPOPROTEIN A-II PRECURSOR (APO-AII) & {$[116],[115],[118],[41]$} \\
\hline P08697 & ALPHA-2-ANTIPLASMIN PRECURSOR & {$[116],[41]$} \\
\hline Q14624 & $\begin{array}{l}\text { INTER-ALPHA-TRYPSIN INHIBITOR HEAVY CHAIN H4 } \\
\text { PRECURSOR }\end{array}$ & {$[116],[41]$} \\
\hline P01042 & $\begin{array}{l}\text { KININOGEN PRECURSOR (ALPHA-2-THIOL PROTEINASE } \\
\text { INHIBITOR) }\end{array}$ & {$[116],[41]$} \\
\hline P02743 & SERUM AMYLOID P-COMPONENT PRECURSOR (SAP) & {$[116],[41]$} \\
\hline
\end{tabular}

It is noteworthy that in many instances MS/MS spectra were matched to several peptides of a particular hypothetical protein leading to substantial sequence coverage for that gene trancscript. Therefore measurements can not easily be discarded as mere coincidence and their match as "one hit wonders". Although the sample preparation approaches and detection techniques were similar, the protein identification results were quite different. At this point it is not clear what might have contributed to the difference in the reported protein composition of CSF. Extending the review to all recent protein profiling reports using sensitive mass spectrometry techniques that reported hypothetical proteins reveals a similar astonishing end result. From several hundred 
Table 4

Details of all gene transcripts of unknown function that were reported in recent protein profiling reports using sensitive mass spectrometry techniques and were identified in at least two independent experiments. Note that in the case of the neurosecretory protein homologue a number of peptides with overlapping protein sequence coverage were reported

$\begin{array}{llll}\begin{array}{l}\text { Database Reference } \\ \text { DJ717I23.1 }\end{array} & \begin{array}{l}\text { Description of potential function } \\ \text { Mus musculus adult male testis cDNA, Mus musculus 16 days } \\ \text { neonate thymus cDNA }\end{array} & \begin{array}{l}\text { Sequence } \\ \text { not reported }\end{array} \\ \text { Q9UDW8 } & \begin{array}{l}\text { WUGSC:H DJ0747G18.3 protein, neurosecretory protein VGF } \\ \text { precursor (VGF8a) in rat with 90\% identity with human VGF }\end{array} & \begin{array}{l}\text { residue 378-397, residue 391-413, } \\ \text { 477-500,605-635 }\end{array} \\ & \begin{array}{l}\text { [41; 130] } \\ \text { precursor }\end{array} & \text { n/a }\end{array}$

gene transcripts described only 3 of them were common in at least two reports. None of the new proteins was common to all reports. Table 4 shows details of all gene transcripts of unknown function that were identified in at least two independent experiments. However, the novel proteins found to be in common in those studies appear to be relevant to CNS and, in one case, a nerve growth factor associated protein that clearly has to be brain-derived was detected. Despite the apparent difficulty of these high-throughput protein profiling methods to demonstrate consistency and reproducibility for low level proteins at this point, technological advances and improvements will enable researchers to mine the CSF protein contents for unknown proteins using LC-MS based detection techniques in the future.

\subsection{Comparative protein analysis}

Most of the important comparative proteomic analyses of CSF proteins to date have employed gel-based techniques that allow the observation of a consistent segment of CSF protein complement and facilitated the observation of the CSF protein dynamics. Unfortunately, investigations of this type will clearly be limited to high abundance proteins that might not have a direct connection to the disease mechanism, but could rather represent a system response of the CSF tissue itself. However, little knowledge exists about the degree of influence and effect of different protein and peptide post-translational modifications on the structure and function of the altered brain. The molecular variations caused by post-translational modifications, such as as phosphorylation, acetylation, glycation, glycosylation and truncation over time and their relationship to the pathophysiology of psychiatric and neurodegenerative diseases still is largely unknown and remains to be discovered. For focused studies on a limited number of proteins on the cause and effect of post-translationally modified proteins in neurological diseases, gel-based comparative analysis methods are the appropriate set of analysis tools today. It is apparent that the use of opti- mized LC-MS methods show advantages in sensitivity and dynamic range over gel-based techniques, while currently eliminating the ability to easily monitor and study crucial information about protein isoforms.

\subsection{Challenges in CSF protein analysis}

The complexity of 2D-Gel spot patterns illustrates the intricacy of working human tissue, where most of the differences are associated with natural variations between individuals. In the analysis of multifactorial brain diseases, such as schizophrenia and Alzheimer's disease, the challenge for proteomics is to provide methods and tools to filter out the disease-specific changes from inherent differences that simply discriminate one individual from another. Much of the recent methodological developments have concentrated on analysis of peptides as surrogates for their parent proteins. For microorganisms, where the one gene equals one protein equals one function dogma has a greater validity, this methodology is extremely powerful, but it is inadequate for the elucidation of many aspects of cellular function in higher organisms. In higher eukaryotes, cells actively control the partitioning of proteins between individual transcriptional/post-translational isoforms as part of normal cellular function and as part of tissue-specific interactions between different cell types. If new approaches are to be useful in studying higher eukaryotes, the technique will have to be able to detect and characterize these changes in individual protein isoforms. These isoforms may arise from transcriptional variation, post-translational modifications processes such as phosphorylation and specific proteolytic fragmentation processes. MS identification of shorttryptic peptides is sufficient for gene level assignments, but is inadequate for isoform characterization at either the transcriptional or post-translational level. Protein variants at the transcriptional level are increasingly well characterized, but what is needed are rapid methods for validation of the complete protein sequence for consistency with the genome sequence combined with meth- 
ods for detailed analysis of those regions which differ from the genome sequence. This would include detection and characterization of alternative splicing, detailed analysis of unknown sequences caused by processes such as RNA editing and characterization of post-translational modifications.

\subsection{The protein isoform challenge}

In most organs, e.g., muscle, cells are more homogenous in their phenotypes, transcriptomes, proteomes and cellular interaction. In brain, however, transcriptomes, proteomes, morphological phenotypes and interactive connections vary widely within the neurons and glia. Alternate splicing of pre-mRNA is now known to be an important mechanism for gene regulation in many organisms. There is now good evidence that almost $50 \%$ of all genes in the human genome might be subject to transcriptional variation by RNA splicing and editing [44]. There is also ample evidence that specific isoforms are often produced only in particular developmental or environmental context, e.g., response to various kinds of stress. In fact, a recent study investigating variation in alternative splicing across human tissues showed that brain tissue had the most pronounced differences in splicing patterns in all the human tissues investigated. In particular, brain tissue had the highest level of exon skipping and the most distinctive patterns of alternative splicing, suggesting a unusually high level of alternative pre-mRNA splicing events generating brain tissue specific mRNA and protein isoforms [45]. Given the functional importance of alternative splicing and the fact that splice variants are often difficult to recognize in genomic sequencing, it is important that characterizations of proteins in proteomic databases include identifications at the transcriptional level. This can be achieved either by protein identification at the gene level and verification of its mass by mass spectrometry or by characterization of peptide fragments that cover the entire protein sequence. For unexpected splice variants, both analysis approaches may be necessary.

\subsection{The bioinformatics challenge}

It is apparent today that the biggest challenge for gelfree based protein analysis methods does not arise from the dynamic range of the CSF protein composition and the sensitivity required to detect low abundance proteins, but from the fact that these techniques produce massive amounts of data that require careful interpreta- tion. The complete and precise extraction of information from mass spectra as well as the truthful interpretation of information contained within those spectra is the principal challenge in most LC-MS based approaches. Human knowledge and understanding is undoubtedly the most sensitive "detector" for the accurate analysis of mass spectrometry data, but, unfortunately, also the most inefficient. Algorithms for the extraction of information from mass spectral data sets need to be capable of interpreting all the information in the spectra, regardless of the quality of the underlying data. Most mass spectrometry-based protein studies rely on matching peptides masses or fragmentation spectra from protein digests with those found in protein databases [46,47]. This approach has dramatically increased our ability to identify known proteins, but the approach is limited to genomes and proteins that are already sequenced and functionally annotated. A complete map of the human genome has been published recently [48], but the functional annotation and understanding of the human genome is incomplete. The most common approach to generate protein sequence databases for use in protein database searches is global gene annotation using primary amino acid sequence analysis tools and sequence databases. Genes of unknown function are predicted and annotated under the premise that proteins of similar structure usually have similar function. However, this approach is limited by its simplistic assumptions that in many cases have not been experimentally verified. Analysis of mass spectral data, therefore, cannot be limited to spectral correlation only, but needs to be comprised of algorithms capable of interpreting data in de novo approaches, desirable in a completely unsupervised mode. Error tolerant search strategies that allow protein identification by sequence similarity searches from a partially interpreted tandem mass spectrum can detect protein sequences generated by alternative splicing events. Therefore, bypassing protein database searches using genomic searching approaches for the interpretation of mass spectrometry data will dominate approaches for the characterization of new protein variants and their identification at the transcriptional level in the characterization of neurological disease phenotypes.

\subsection{Experimental challenges}

A considerable amount of time has been dedicated in most large-scale protein analysis efforts, most notably, the human plasma proteome project, to investigate and determine the influence of various technical variables 
during specimen collection, sample handling and storage. Reproducible detection of CSF protein will require a similar standardization for the specimen collection, sample handling and storage. As discussed above, the rate of CSF formation fluctuates during a 24 hour period and these well established circadian fluctuations will affect quantitative protein measurements and will need to be considered during normalization in longitudinal studies. Similarly, the partial removal of CSF during longitudinal study will affect the total protein concentration and dilute potentially low abundance proteins even further. Potential contamination of CSF fluid with blood components during the lumbar puncture procedure need to be carefully monitored. In particular, blood contamination can induce protein degradation during sample handling by proteases derived from blood. The degree of contamination with blood is usually determined by counting red blood cells, measuring the total protein concentration and monitoring albumin and immunoglobulin profiles. The detection of various blood proteins, e.g., apolipoprotein B or their characteristic peptide fragments has also been suggested as means to assess blood contamination in CSF [40]. However, red blood cells derived proteins may provide the most useful markers of whole blood contamination, since many proteins in CSF are also found in blood. Previously, proteins, such as hemoglobin, carbonic anhydrase I, catalase, and peroxiredoxin have been suggested as highly sensitive markers for blood contamination in CSF fluid [49]. Proteomic studies reporting the presence of these proteins should be reviewed carefully to assess the potential impact of the contamination, in particular, the impact of those contaminants on sample stability due to potential protein degradation. Sample handling between the source and the actual analytical measurement also provides a challenge to the experimental design and analysis of quantitative differential measurements. Preanalytical procedures, such as freezing and thawing cycles can have a rather undesired effect on the quantitative analysis of disease specific markers in CSF. It was shown recently that the loss of disease specific amyloid $\beta$ peptide patterns in the diagnosis of Alzheimer's disease patterns depends on sample pretreatment and peptide detection methods [50].

\section{Conclusion}

The detection of disease-related changes in the brain is the basic target of cerebrospinal fluid analysis. The discovery of disease specific markers will in part depend on the accessibility of those proteins in CSF. The accessibility of potential disease markers is affected by their release from brain parenchyma and rapid distribution into the CSF. Very little is currently known about those barriers and the exact distribution pattern of molecular analytes in the brain and the CSF tissue. Therefore, understanding and interpretation of disease markers in CSF will primarily depend on our progress in the understanding of the dynamic changes in the CSF compartment.

Starting with IEF separations that allowed the detection of $40 \mathrm{CSF}$ protein bands 27 years ago to the generation of 700 individually separated spots in 2-DE maps from CSF proteins, and finally the detection and identification of several thousand peptides by LC/MS methods representing several hundred proteins in CSF today, represent an impressive increase in the number of proteins detected over the past 3 decades. The fifty fold increase in the number of detected CSF proteins, although impressive from a historical perspective, is dwarfed by the potential number of proteins in CSF tissue that could easily exceed several hundred thousand proteins or protein fragments.

We can make a simple assessment of the magnitude of a neurological event that we might be able to study using CSF protein profiling techniques. The human brain consist of approximately 500 billion $\left(5 \times 10^{11}\right)$ cells, in which the neurons are three times outnumbered by glial cells. Assuming that any protein derived from one of the brain cells instantaneously and evenly equilibrates into the ECF and ultimately transfers into $\sim 150 \mathrm{~mL}$ of CSF, we can make a crude assessment of the molecular events that we can currently monitor using available detection technologies. The lumbar puncture sampling technique allows us to withdraw 10-20 mL of CSF at a time, which represents approximately $1 / 10$ th of the entire CSF volume. At a detection limit of several attomoles the presence of at least 1,000,000 molecules of one species in the sample CSF is required to be detected with currently available commercial mass spectrometers. Given a single molecule detection technique in the future that we can apply to the detection of brain-derived proteins in CSF, molecular events that produce hundreds of molecules of the same species should be measurable. This implies that current proteomic techniques already provide us with the tools that allow us to monitor and characterize significant molecular events in the brain through the analysis of CSF proteins.

However, the ability to detect and quantify molecules in a massively parallel manner, even at very low levels, 
should not be made in isolation of present knowledge and available hypotheses. Review of the available literature on clinically focused protein measurements and current protein compositional profiling efforts in this article indicates that successful discovery of disease marker relevant molecules is not only related to the availability of powerful analytical tools for CSF protein analysis, but also a function of understanding protein measurements as a function of the physiology of CSF.

Traditional clinical measurements that allow the study of individual proteins representing a known or proposed disease mechanism at a remarkably low concentration demonstrate a lack of systematic approach for the discovery of protein disease markers. This reductionist approach in which researchers focus on one component of a biological system at a time - a gene or a protein- and then they try to take the knowledge about individual components up the system level, not only makes a measurement that is taken out of context with the rest of a common molecular pathway, but also is divorced from the context of the whole organism. The pathophysiology of psychiatric as well as neurodegenerative diseases should be regarded as multifactorial, and their complexity needs to be understood at the multimolecular level. It should be noted that revealing such multifactorial changes and their dynamics over time, can not rely on one technique only. Several complementary strategies, including current clinical measurements, current and future protein profiling approaches as well as basic biochemical studies should be considered for the elucidation of molecular characteristics of complex neurological diseases.

Review of the available CSF protein data from clinically-based quantitative measurements show that those measurements, with the exception of albu$\mathrm{min} / \mathrm{IgG}$ ratio were focused on proteins believed to be low abundance proteins. In contrast our summary of results from current protein studies using gel-free, separation-based analysis techniques indicate that proteins that are generally considered high-abundant proteins were almost exclusively investigated in those efforts. Since it is known that many high-abundant proteins are largely blood derived or in some cases synthesized locally in CP and not directly derived from brain itself, most of the separation-based analysis methods have been focusing on exploring changes that are likely responses of the CSF tissue to general CNS system challenges. On the other hand, clinically focused quantitative measurements were primarily targeting proteins believed to be brain-derived; however, given the fact that the antibody-based techniques applied to CSF mea- surements were largely not specifically developed for brain-derived proteins, there is some question to the specificity of those measurements. It is not clear to what extent the proteins derived from blood or directly from brain contributed in those measurements.

It is interesting to note that current shotgun sequencing techniques are mostly not conducted as quantitative measurements and often eliminate exactly those proteins from the analysis, e.g., serum albumin and IgG that have been crucial in the diagnosis of neurological disease and the understanding of physiological changes in CSF in the past 100 years. Approaches to quantify changes in CSF composition $[51,52]$ are just getting started and extend the pure cataloging of proteins with some quantitative information. However, they do not yet extend to quantitative determination of protein isoforms. Advancements in protein mass spectrometry that expand the current qualitative and quantitative measurements of peptides to entire proteins and their related isoforms will enable us in the future to complement differential measurements provided by today's gel-based analysis tools. Top down proteomics methods of mass spectrometry that are currently in development, fulfill many of the requirements for protein isoform analysis and can start to fill the current gap in the analysis of low levels of protein isoforms [53].

Many CNS diseases, such as Alzheimer's disease [54], are most likely heterogeneous diseases that do not result from a single, specific event, but rather are the end result of a complex series of aberrant biological events involving the neural and possibly nonneural systems [55]. The precise definition of such a complex phenotype requires the assessment of several physiological aspects of the same individual that reflect one or several fundamental features of the neuropathology. There is a need to establish a theoretical concept and experimental evidence for the mechanistic relation between marker concentration in CSF and the disease process. In addition to a panel of markers that reflect the state of neuropathology correctly, phenotype characterization might also have to include measurements that characterize the relevance of the analytical measurement in the sampled biological system, i.e., CSF. A reliable quantitative measurement of a disease marker, therefore, might have to include a specific marker for blood-CSF barrier functionality and integrity in addition to a specific brain-derived disease marker [56]. Essentially, all the factors influencing the formation and distribution of molecular analytes in CSF that were discussed in this article might have to be considered.

Great progress has been made in the past 20 years in characterizing the clinical phenotype using powerful 
neurophysiological test batteries and for the diagnosis and monitoring of disease progression. More importantly, procedures for the clinical assessment have advanced beyond the stage of diagnosing by a process of exclusion towards well-validated algorithms for identifying the positive clinical phenotypes of the disease. While those systematic efforts for the accurate clinical diagnosis of neurological diseases provide a diagnosis with a high degree of accuracy for some diseases, a molecular characterization of a phenotype could offer the unique opportunity to diagnose the neurological diseases in its asymptomatic stage.

\section{References}

[1] J. Choudhary and S.G. Grant, Proteomics in postgenomic neuroscience: the end of the beginning, Nat. Neurosci. 7 (2004), 440-445.

[2] S.I. Kim, H. Voshol, O.J. van, T.G. Hastings, M. Cascio, and M.J. Glucksman, Neuroproteomics: expression profiling of the brain's proteomes in health and disease, Neurochem. Res. 29 (2004), 1317-1331.

[3] W.M. Freeman and S.E. Hemby, Proteomics for protein expression profiling in neuroscience, Neurochem. Res. 29 (2004), 1065-1081.

[4] X. Yuan and D.M. Desiderio, Proteomics analysis of human cerebrospinal fluid, J. Chromatogr. B Analyt. Technol. Biomed. Life Sci. 815 (2005), 179-189.

[5] Davson Hugh, Physiology of the Cerebrospinal Fluid, J \& A Churchill, 104 Gloucester Place, London, 1967.

[6] Fishman and A. Robert, Cerebrospinal Fluid In Disease of the Nervous System, W.B. Saunders Company, Philadelphia, 80 A.D..

[7] R. Mollanji, R. Bozanovic-Sosic, A. Zakharov, L. Makarian, and M.G. Johnston, Blocking cerebrospinal fluid absorption through the cribriform plate increases resting intracranial pressure, Am. J. Physiol Regul. Integr. Comp Physiol 282 (2002), R1593-R1599.

[8] M. Johnston, A. Zakharov, C. Papaiconomou, G. Salmasi and D. Armstrong, Evidence of connections between cerebrospinal fluid and nasal lymphatic vessels in humans, non-human primates and other mammalian species, Cerebrospinal. Fluid Res. 1 (2004), 2.

[9] Fishman and A. Robert, Cerebrospinal Fluid In Disease of the Nervous System, W.B. Saunders Company, Philadelphia, 80 A.D..

[10] J.H. Wood, Neurobiology of Cerebrospinal Fluid, Plenum Press, New York, 1980.

[11] H. Davson and M.B. Segal, Physiology of the CSF and BloodBrain Barriers, CRC Press, Boca Raton, 1996, 822.

[12] G. Schreiber, A.R. Aldred, T. Thomas, H.E. Birch, P.W. Dickson, G.F. Tu, P.C. Heinrich, W. Northemann, G.J. Howlett and F.A. De Jong, Levels of messenger ribonucleic acids for plasma proteins in rat liver during acute experimental inflammation, Inflammation 10 (1986), 59-66.

[13] G.F. Tu, T. Cole, B.R. Southwell and G. Schreiber, Expression of the genes for transthyretin, cystatin $\mathrm{C}$ and beta A4 amyloid precursor protein in sheep choroid plexus during development, Brain Res. Dev. Brain Res. 55 (1990), 203-208.
[14] CNS Barriers and Modern CSF Diagnostics, VCH Verlagsgesellschaft mbH, Weinheim, D-6945, 2005.

[15] E.J. Thompson, M. Trojano and P. Livrea, Cerebrospinal Fluid Analysis in Multiple Sclerosis, Springer Verlag, Milano, 1996.

[16] M. Edsbagge, M. Tisell, L. Jacobsson and C. Wikkelso, Spinal CSF absorption in healthy individuals, Am. J. Physiol Regul. Integr. Comp Physiol 287 (2004), R1450-R1455.

[17] Z.B. Redzic and M.B. Segal, The structure of the choroid plexus and the physiology of the choroid plexus epithelium, Adv. Drug Deliv. Rev. 56 (2004), 1695-1716.

[18] K. Welch, The principles of physiology of the cerebrospinal fluid in relation to hydrocephalus including normal pressure hydrocephalus, Adv. Neurol. 13 (1975), 247-332.

[19] Fishman and A. Robert, Cerebrospinal Fluid In Disease of the Nervous System, W.B. Saunders Company, Philadelphia, 80 A.D..

[20] C. Nilsson, F. Stahlberg, C. Thomsen, O. Henriksen, M. Herning and C. Owman, Circadian variation in human cerebrospinal fluid production measured by magnetic resonance imaging, Am. J. Physiol 262 (1992), R20-R24.

[21] J.E. Preston, Ageing choroid plexus-cerebrospinal fluid system, Microsc. Res. Tech. 52 (2001), 31-37.

[22] M. Boulton, D. Armstrong, M. Flessner, J. Hay, J.P. Szalai and M. Johnston, Raised intracranial pressure increases CSF drainage through arachnoid villi and extracranial lymphatics, Am. J. Physiol 275 (1998), R889-R896.

[23] T.O. Kleine, R. Hackler and P. Zofel, Age-related alterations of the blood-brain-barrier (bbb) permeability to protein molecules of different size, Z. Gerontol. 26 (1993), 256-259.

[24] H. Stibler, The normal cerebrospinal fluid proteins identified by means of thin-layer isoelectric focusing and crossed immunoelectrofocusing, J. Neurol. Sci. 36 (1978), 273-288.

[25] K.G. Kjellin and A. Siden, Electrofocusing and electrophoresis of cerebrospinal fluid proteins in CNS disorders of known or probable infectious etiology, Eur. Neurol. 16 (1977), 79-89.

[26] K.G. Kjellin and A. Siden, Aberrant CSF protein fractions found by electrofocusing in multiple sclerosis. A study of 26 cases with clinically verified or probable multiple sclerosis and 2 cases with optic neuritis, Eur. Neurol. 15 (1977), 40-50.

[27] J. Klose, Protein mapping by combined isoelectric focusing and electrophoresis of mouse tissues. A novel approach to testing for induced point mutations in mammals, Humangenetik 26 (1975), 231-243.

[28] D. Goldman, C.R. Merril and M.H. Ebert, Two-dimensional gel electrophoresis of cerebrospinal fluid proteins, Clin. Chem. 26 (1980), 1317-1322.

[29] M.G. Harrington and C.R. Merril, Two-dimensional electrophoresis and ultrasensitive silver staining of cerebrospinal fluid proteins in neurological diseases, Clin. Chem. 30 (1984), 1933-1937.

[30] M.G. Harrington, C.R. Merril, D.M. Asher and D.C. Gajdusek, Abnormal proteins in the cerebrospinal fluid of patients with Creutzfeldt-Jakob disease, N. Engl. J. Med. 315 (1986), 279283.

[31] M.G. Harrington, C.R. Merril and E.F. Torrey, Differences in cerebrospinal fluid proteins between patients with schizophrenia and normal persons, Clin. Chem. 31 (1985), 722-726.

[32] L.H. Choe, A. Green, R.S. Knight, E.J. Thompson and K.H. Lee, Apolipoprotein E and other cerebrospinal fluid proteins differentiate ante mortem variant Creutzfeldt-Jakob disease from ante mortem sporadic Creutzfeldt-Jakob disease, Electrophoresis 23 (2002), 2242-2246.

[33] M.G. Harrington, K.H. Lee, M. Yun, T. Zewert, J.E. Bailey and L. Hood, Mechanical precision in two-dimensional elec- 
trophoresis can improve protein spot positional reproducibility, Appl. Theor. Electrophor. 3 (1993), 347-353.

[34] D.E. Terry and D.M. Desiderio, Between-gel reproducibility of the human cerebrospinal fluid proteome, Proteomics 3 (2003), 1962-1979.

[35] J.C. Sanchez, R.D. Appel, O. Golaz, C. Pasquali, F. Ravier, A. Bairoch and D.F. Hochstrasser, Inside SWISS-2DPAGE database, Electrophoresis 16 (1995), 1131-1151.

[36] S. Grunewald, K. Huyben, J.G. de Jong, J.A. Smeitink, E. Rubio, G.H. Boers, H.S. Conradt, U. Wendel and R.A. Wevers, beta-Trace protein in human cerebrospinal fluid: a diagnostic marker for N-glycosylation defects in brain, Biochim. Biophys. Acta 1455 (1999), 54-60.

[37] A. Petzold, G. Keir, A.J. Green, G. Giovannoni and E.J. Thompson, A specific ELISA for measuring neurofilament heavy chain phosphoforms, J. Immunol. Methods 278 (2003), 179-190.

[38] J.N. Lycke, J.E. Karlsson, O. Andersen and L.E. Rosengren, Neurofilament protein in cerebrospinal fluid: a potential marker of activity in multiple sclerosis, J. Neurol. Neurosurg. Psychiatry 64 (1998), 402-404.

[39] G. Maccarrone, D. Milfay, I. Birg, M. Rosenhagen, F. Holsboer, R. Grimm, J. Bailey, N. Zolotarjova and C.W. Turck, Mining the human cerebrospinal fluid proteome by immunodepletion and shotgun mass spectrometry, Electrophoresis 25 (2004), 2402-2412.

[40] J. Zhang, D.R. Goodlett, E.R. Peskind, J.F. Quinn, Y. Zhou, Q. Wang, C. Pan, E. Yi, J. Eng, R.H. Aebersold and T.J. Montine, Quantitative proteomic analysis of age-related changes in human cerebrospinal fluid, Neurobiol. Aging 26 (2005), 207-227.

[41] A.F. Huhmer, R.G. Biringer, H. Amato and M.G. Harrington, Shotgun sequencing of the human cerebrospinal fluid proteome using 2D Chromatography in combination with linear ion trap mass spectrometry. Presented at the Annual German Electrophoresis Society meeting, Munich (Sept 14-17, 2003).

[42] P. Davidsson, M. Puchades and K. Blennow, Identification of synaptic vesicle, pre- and postsynaptic proteins in human cerebrospinal fluid using liquid-phase isoelectric focusing, Electrophoresis 20 (1999), 431-437.

[43] A.F. Huhmer, R.G. Biringer, H. Amato and M.G. Harrington, Analysis of deglycosylated human cerebrospinal fluid using Fourier Transform Ion Trap Mass Spectrometry, In preparation.

[44] G.C. Roberts and C.W. Smith, Alternative splicing: combinatorial output from the genome, Curr. Opin. Chem. Biol. 6 (2002), 375-383

[45] G. Yeo, D. Holste, G. Kreiman and C.B. Burge, Variation in alternative splicing across human tissues, Genome Biol $\mathbf{5}$ (2004), R74.

[46] A. Shevchenko, O.N. Jensen, A.V. Podtelejnikov, F. Sagliocco, M. Wilm, O. Vorm, P. Mortensen, A. Shevchenko, H. Boucherie and M. Mann, Linking genome and proteome by mass spectrometry: large-scale identification of yeast proteins from two dimensional gels, Proc. Natl. Acad. Sci. USA 93 (1996), 14440-14445.

[47] J.R. Yates, III, J.K. Eng and A.L. McCormack, Mining genomes: correlating tandem mass spectra of modified and unmodified peptides to sequences in nucleotide databases, Anal. Chem. 67 (1995), 3202-3210.

[48] E.S. Lander, L.M. Linton, B. Birren, C. Nusbaum, M.C.Zody, J. Baldwin, K. Devon, K. Dewar, M. Doyle, W. FitzHugh, R. Funke, D. Gage, K. Harris, A. Heaford, J. Howland, L. Kann, J. Lehoczky, R. LeVine, P. McEwan, K. McKernan, J.
Meldrim, J.P. Mesirov, C. Miranda, W. Morris, J. Naylor, C. Raymond, M. Rosetti, R. Santos, A. Sheridan, C. Sougnez, N. Stange-Thomann, N. Stojanovic, A.Subramanian, D.Wyman, J.Rogers, J.Sulston, R.Ainscough, S. Beck, D. Bentley, J. Burton, C. Clee, N. Carter, A. Coulson, R. Deadman, P. Deloukas, A. Dunham, I. Dunham, R. Durbin, L. French, D. Grafham, S. Gregory, T. Hubbard, S. Humphray, A. Hunt, M. Jones, C. Lloyd, A. McMurray, L. Matthews, S. Mercer, S. Milne, J.C. Mullikin, A. Mungall, R. Plumb, M. Ross, R. Shownkeen, S. Sims, R.H. Waterston, R.K. Wilson, L.W. Hillier, J.D. McPherson, M.A. Marra, E.R. Mardis, L.A. Fulton, A.T. Chinwalla, K.H. Pepin, W.R. Gish, S.L. Chissoe, M.C. Wendl, K.D. Delehaunty, T.L. Miner, A. Delehaunty, J.B. Kramer, L.L. Cook, R.S. Fulton, D.L. Johnson, P.J. Minx, S.W. Clifton, T. Hawkins, E. Branscomb, P. Predki, P. Richardson, S. Wenning, T. Slezak, N. Doggett, J.F. Cheng, A. Olsen, S. Lucas, C. Elkin, E. Uberbacher, M. Frazier, R.A. Gibbs, D.M. Muzny, S.E. Scherer, J.B. Bouck, E.J. Sodergren, K.C. Worley, C.M. Rives, J.H. Gorrell, M.L. Metzker, S.L. Naylor, R.S. Kucherlapati, D.L. Nelson, G.M. Weinstock, Y. Sakaki, A. Fujiyama, M. Hattori, T. Yada, A. Toyoda, T. Itoh, C. Kawagoe, H. Watanabe, Y. Totoki, T. Taylor, J. Weissenbach, R. Heilig, W. Saurin, F. Artiguenave, P. Brottier, T. Bruls, E. Pelletier, C. Robert, P. Wincker, D.R. Smith, L. Doucette-Stamm, M. Rubenfield, K. Weinstock, H.M. Lee, J. Dubois, A. Rosenthal, M. Platzer, G. Nyakatura, S. Taudien, A. Rump, H. Yang, J. Yu, J. Wang, G. Huang, J. Gu, L. Hood, L. Rowen, A. Madan, S. Qin, R.W. Davis, N.A. Federspiel, A.P. Abola, M.J. Proctor, R.M. Myers, J. Schmutz, M. Dickson, J. Grimwood, D.R. Cox, M.V. Olson, R. Kaul, C. Raymond, N. Shimizu, K. Kawasaki, S. Minoshima, G.A. Evans, M. Athanasiou, R. Schultz, B.A. Roe, F. Chen, H. Pan, J. Ramser, H. Lehrach, R. Reinhardt, W.R. McCombie, B.M. de la, N. Dedhia, H. Blocker, K. Hornischer, G. Nordsiek, R. Agarwala, L. Aravind, J.A. Bailey, A. Bateman, S. Batzoglou, E. Birney, P. Bork, D.G. Brown, C.B. Burge, L. Cerutti, H.C. Chen, D. Church, M. Clamp, R.R. Copley, T. Doerks, S.R. Eddy, E.E. Eichler, T.S. Furey, J. Galagan, J.G. Gilbert, C. Harmon, Y. Hayashizaki, D. Haussler, H. Hermjakob, K. Hokamp, W. Jang, L.S. Johnson, T.A. Jones, S. Kasif, A. Kaspryzk, S. Kennedy, W.J. Kent, P. Kitts, E.V. Koonin, I. Korf, D. Kulp, D. Lancet, T.M. Lowe, A. McLysaght, T. Mikkelsen, J.V. Moran, N. Mulder, V.J. Pollara, C.P. Ponting, G. Schuler, J. Schultz, G. Slater, A.F. Smit, E. Stupka, J. Szustakowski, D. Thierry-Mieg, J. Thierry-Mieg, L. Wagner, J. Wallis, R. Wheeler, A. Williams, Y.I. Wolf, K.H. Wolfe, S.P. Yang, R.F. Yeh, F. Collins, M.S. Guyer, J. Peterson, A. Felsenfeld, K.A. Wetterstrand, A. Patrinos, M.J. Morgan, J.P. de, J.J. Catanese, K. Osoegawa, H. Shizuya, S. Choi and Y.J. Chen, Initial sequencing and analysis of the human genome, Nature 409 (2001), 860-921.

[49] J.S. You, V. Gelfanova, M.D. Knierman, F.A. Witzmann, M. Wang and J.E. Hale, The impact of blood contamination on the proteome of cerebrospinal fluid, Proteomics 5 (2004), 290296.

[50] M. Bibl, H. Esselmann, M. Otto, P. Lewczuk, L. Cepek, E. Ruther, J. Kornhuber and J. Wiltfang, Cerebrospinal fluid amyloid beta peptide patterns in Alzheimer's disease patients and nondemented controls depend on sample pretreatment: indication of carrier-mediated epitope masking of amyloid beta peptides, Electrophoresis 25 (2004), 2912-2918.

[51] J. Zhang, D.R. Goodlett, E.R. Peskind, J.F. Quinn, Y. Zhou, Q. Wang, C. Pan, E. Yi, J. Eng, R.H. Aebersold and T.J. Montine, Quantitative proteomic analysis of age-related changes 
in human cerebrospinal fluid, Neurobiol. Aging 26 (2005), 207-227.

[52] T. Tsuji, A. Shiozaki, R. Kohno, K. Yoshizato and S. Shimohama, Proteomic profiling and neurodegeneration in Alzheimer's disease, Neurochem. Res. 27 (2002), 1245-1253.

[53] F. Meng, B.J. Cargile, L.M. Miller, A.J. Forbes, J.R. Johnson and N.L. Kelleher, Informatics and multiplexing of intact protein identification in bacteria and the archaea, Nat. Biotechnol. 19 (2001), 952-957.

[54] C.E. Teunissen, V.J. de, H.W. Steinbusch and B.C. De, Biochemical markers related to Alzheimer's dementia in serum and cerebrospinal fluid, Neurobiol. Aging 23 (2002), 485-508.

[55] Z.S. Khachaturian, The challenges of developing and validating molecular and biochemical markers of Alzheimer's disease, Neurobiol. Aging 23 (2002), 509-511.

[56] C.E. Teunissen and P. Scheltens, Biomarkers for Alzheimer's disease. Which way to go? Neurobiol. Aging 25 (2004), 695696.

[57] Fishman and A. Robert, Cerebrospinal Fluid In Disease of the Nervous System, W.B. Saunders Company, Philadelphia, 80 A.D..

[58] J.R. Geigy, Scientific Tables, Geigy Limited, Pharmacentical Division Macclesfield, Basel, 1970.

[59] Fishman and A. Robert, Cerebrospinal Fluid In Disease of the Nervous System, W.B. Saunders Company, Philadelphia, 80 A.D..

[60] M.J. Garton, G. Keir, M.V. Lakshmi and E.J. Thompson, Agerelated changes in cerebrospinal fluid protein concentrations, J. Neurol. Sci. 104 (1991), 74-80.

[61] K. Blennow, A. Wallin, P. Davidsson, P. Fredman, C.G. Gottfries and L. Svennerholm, Intra-blood-brain-barrier synthesis of immunoglobulins in patients with dementia of the Alzheimer type, Alzheimer Dis. Assoc. Disord. 4 (1990), 79 86.

[62] C.T. Lutz, S.H. Cornell and J.A. Goeken, Establishment of a reference interval for beta 2-microglobulin in cerebrospinal fluid with use of two commercial assays, Clin. Chem. 37 (1991), 104-107.

[63] L. Terrisse, J. Poirier, P. Bertrand, A. Merched, S. Visvikis, G. Siest, R. Milne and E. Rassart, Increased levels of apolipoprotein D in cerebrospinal fluid and hippocampus of Alzheimer's patients, J. Neurochem. 71 (1998), 1643-1650.

[64] K. Blennow, P. Davidsson, A. Wallin and R. Ekman, Chromogranin A in cerebrospinal fluid: a biochemical marker for synaptic degeneration in Alzheimer's disease? Dementia 6 (1995), 306-311.

[65] H.L. Muller, Y. Oh, T. Lehrnbecher, W.F. Blum and R.G. Rosenfeld, Insulin-like growth factor-binding protein-2 concentrations in cerebrospinal fluid and serum of children with malignant solid tumors or acute leukemia, J. Clin. Endocrinol. Metab 79 (1994), 428-434.

[66] F. Padberg, W. Feneberg, S. Schmidt, M.J. Schwarz, D. Korschenhausen, B.D. Greenberg, T. Nolde, N. Muller, H. Trapmann, N. Konig, H.J. Moller and H. Hampel, CSF and serum levels of soluble interleukin-6 receptors (sIL-6R and sgp130), but not of interleukin-6 are altered in multiple sclerosis, $J$. Neuroimmunol. 99 (1999), 218-223.

[67] M. Landen, B. Grenfeldt, P. Davidsson, M. Stridsberg, B. Regland, C.G. Gottfries and K. Blennow, Reduction of chromogranin $\mathrm{A}$ and $\mathrm{B}$ but not $\mathrm{C}$ in the cerebrospinal fluid in subjects with schizophrenia, Eur. Neuropsychopharmacol. 9 (1999), 311-315.

[68] H.L. Muller, Y. Oh, S.E. Gargosky, T. Lehrnbecher, R.L. Hintz and R.G. Rosenfeld, Concentrations of insulin-like growth factor (IGF)-binding protein-3 (IGFBP-3), IGF, and IGFBP3 protease activity in cerebrospinal fluid of children with leukemia, central nervous system tumor, or meningitis, J. Clin. Endocrinol. Metab 77 (1993), 1113-1119.

[69] I. Kohira, T. Tsuji, H. Ishizu, Y. Takao, A. Wake, K. Abe and S. Kuroda, Elevation of neuron-specific enolase in serum and cerebrospinal fluid of early stage Creutzfeldt-Jakob disease, Acta Neurol. Scand. 102 (2000), 385-387.

[70] G. Keir, N. Tasdemir and E.J. Thompson, Cerebrospinal fluid ferritin in brain necrosis: evidence for local synthesis, Clin. Chim. Acta 216 (1993), 153-166.

[71] K. Baraczka, K. Nekam, T. Pozsonyi, L. Jakab, M. Szongoth and M. Sesztak, Concentration of soluble adhesion molecules (sVCAM-1, sICAM-1 and sL-selectin) in the cerebrospinal fluid and serum of patients with multiple sclerosis and systemic lupus erythematosus with central nervous involvement, Neuroimmunomodulation 9 (2001), 49-54.

[72] S.F. Hansson, M. Puchades, K. Blennow, M. Sjogren and P. Davidsson, Validation of a prefractionation method followed by two-dimensional electrophoresis - Applied to cerebrospinal fluid proteins from frontotemporal dementia patients, Proteome. Sci. 2 (2004), 7.

[73] L.E. Rosengren, C. Wikkelso and L. Hagberg, A sensitive ELISA for glial fibrillary acidic protein: application in CSF of adults, J. Neurosci. Methods 51 (1994), 197-204.

[74] N. Andreasen, E. Vanmechelen, V.d. Van, P. Davidsson, C. Hesse, S. Tarvonen, I. Raiha, L. Sourander, B. Winblad and $\mathrm{K}$. Blennow, Cerebrospinal fluid tau protein as a biochemical marker for Alzheimer's disease: a community based follow up study, J. Neurol. Neurosurg. Psychiatry 64 (1998), 298-305.

[75] R.M. Salomon, B. Ripley, J.S. Kennedy, B. Johnson, D. Schmidt, J.M. Zeitzer, S. Nishino and E. Mignot, Diurnal variation of cerebrospinal fluid hypocretin-1 (Orexin-A) levels in control and depressed subjects, Biol. Psychiatry 54 (2003), 96-104.

[76] A.J. Green, R.J. Harvey, E.J. Thompson and M.N. Rossor, Increased tau in the cerebrospinal fluid of patients with frontotemporal dementia and Alzheimer's disease, Neurosci. Lett. 259 (1999), 133-135.

[77] H. Tumani, G. Shen, J.B. Peter and W. Bruck, Glutamine synthetase in cerebrospinal fluid, serum, and brain: a diagnostic marker for Alzheimer disease? Arch. Neurol. 56 (1999), 1241-1246.

[78] H.V. Nikkila, A. Ahokas, K. Wahlbeck, R. Rimon and L.C. Andersson, Neopterin and macrophage inflammatory protein1alpha in the cerebrospinal fluid of schizophrenic patients: no evidence of intrathecal inflammation, Neuropsychobiology $\mathbf{4 6}$ (2002), 169-172.

[79] G. Hsich, K. Kenney, C. Gibbs Jr., J.H. Lee and M.G. Harrington, The 14-3-3 Brain Protein in Cerebrospinal Fluid as a marker for.transmissible spongiform encephalopathies, The New England Journal of. Medicine 335, 924-930; P. Beaudry, P. Cohen, J.P. Brandel, N. asnerie-Laupretre, S. Richard, J.M. Launay and J.L. Laplanche, 14-3-3 protein, neuron-specific enolase, and S-100 protein in cerebrospinal fluid of patients with Creutzfeldt-Jakob disease, Dement. Geriatr. Cogn Disord. 10 (1999), 40-46.

[80] J. Saez-Valero, G. Sberna, C.A. McLean and D.H. Small, Molecular isoform distribution and glycosylation of acetylcholinesterase are altered in brain and cerebrospinal fluid of patients with Alzheimer's disease, J. Neurochem. 72 (1999), 1600-1608.

[81] R. Prior, U. Monning, U. Schreiter-Gasser, A. Weidemann, K. Blennow, C.G. Gottfries, C.L. Masters and K. Beyreuther, 
Quantitative changes in the amyloid beta A4 precursor protein in Alzheimer cerebrospinal fluid, Neurosci. Lett. 124 (1991), 69-73.

[82] M.R. Palmert, M.B. Podlisny, D.S. Witker, T. Oltersdorf, L.H. Younkin, D.J. Selkoe and S.G. Younkin, The beta-amyloid protein precursor of Alzheimer disease has soluble derivatives found in human brain and cerebrospinal fluid, Proc. Natl. Acad. Sci. USA 86 (1989), 6338-6342.

[83] N.A. Clarke, A.W. Procter, M.T. Webster, P.T. Francis, A.D. Hodgkiss and D.M. Bowen, Effect of Li+ therapy and site of origin on cerebrospinal fluid beta-amyloid precursor protein derivatives, Biochem. Soc. Trans. 21(Pt 3) (1993), 242S.

[84] G. Franz, R. Beer, A. Kampfl, K. Engelhardt, E. Schmutzhard, H. Ulmer and F. Deisenhammer, Amyloid beta 1-42 and tau in cerebrospinal fluid after severe traumatic brain injury, $\mathrm{Neu}$ rology 60 (2003), 1457-1461.

[85] M. Lindh, M. Blomberg, M. Jensen, H. Basun, L. Lannfelt, B. Engvall, H. Scharnagel, W. Marz, L.O. Wahlund and R.F. Cowburn, Cerebrospinal fluid apolipoprotein E (apoE) levels in Alzheimer's disease patients are increased at follow up and show a correlation with levels of tau protein, Neurosci. Lett. 229 (1997), 85-88.

[86] A. Merched, J.M. Serot, S. Visvikis, D. Aguillon, G. Faure and G. Siest, Apolipoprotein E, transthyretin and actin in the CSF of Alzheimer's patients: relation with the senile plaques and cytoskeleton biochemistry, FEBS Lett 425 (1998), 225-228.

[87] M. Shoji and M. Kanai, Cerebrospinal fluid Abeta 40 and Abeta42: Natural course and clinical usefulness, $J$. Alzheimers. Dis. 3 (2001), 313-321.

[88] T. Jimi, Y. Wakayama, S. Shibuya, H. Nakata, T. Tomaru, Y. Takahashi, K. Kosaka, T. Asano and K. Kato, High levels of nervous system-specific proteins in cerebrospinal fluid in patients with early stage Creutzfeldt-Jakob disease, Clin. Chim. Acta 211 (1992), 37-46.

[89] R. Press, M. Pashenkov, J.P. Jin and H. Link, Aberrated levels of cerebrospinal fluid chemokines in Guillain-Barre syndrome and chronic inflammatory demyelinating polyradiculoneuropathy, J. Clin. Immunol. 23 (2003), 259-267.

[90] J.C. Sanchez, E. Guillaume, P. Lescuyer, L. Allard, O. Carrette, A. Scherl, J. Burgess, G.L. Corthals, P.R. Burkhard and D.F. Hochstrasser, Cystatin C as a potential cerebrospinal fluid marker for the diagnosis of Creutzfeldt-Jakob disease, Proteomics 4 (2004), 2229-2233.

[91] C. Ferrarese, I. Appollonio, M. Frigo, S. Meregalli, R. Piolti, F. Tamma and L. Frattola, Cerebrospinal fluid levels of diazepam-binding inhibitor in neurodegenerative disorders with dementia, Neurology 40 (1990), 632-635.

[92] L. Verdugo-Diaz, C. Morgado-Valle, G. Solis-Maldonado and R. Drucker-Colin, Determination of dopamine-releasing protein (DARP) in cerebrospinal fluid of patients with neurological disorders, Arch. Med. Res. 28 (1997), 577-581.

[93] H. Reiber, Cerebrospinal fluid-physiology, analysis and interpretation of protein patterns for diagnosis of neurological diseases, Mult. Scler. 4 (1998), 99-107.

[94] H. Hampel, S.J. Teipel, F. Padberg, A. Haslinger, M. Riemenschneider, M.J. Schwarz, H.U. Kotter, M. Scheloske, K. Buch, S. Stubner, R. Dukoff, R. Lasser, N. Muller, T. Sunderland, S.I. Rapoport and H.J. Moller, Discriminant power of combined cerebrospinal fluid tau protein and of the soluble interleukin6 receptor complex in the diagnosis of Alzheimer's disease, Brain Res 823 (1999), 104-112.

[95] A. Garlind, A. Brauner, B. Hojeberg, H. Basun and M. Schultzberg, Soluble interleukin-1 receptor type II levels are elevated in cerebrospinal fluid in Alzheimer's disease patients, Brain Res 826 (1999), 112-116.

[96] J.L. Frederiksen and J.N. Whitaker, Cerebrospinal fluid myelin basic protein-like material in acute monosymptomatic optic neuritis, Acta Neurol. Scand. 94 (1996), 303-309.

[97] I. Zerr, M. Bodemer, S. Racker, S. Grosche, S. Poser, H.A. Kretzschmar and T. Weber, Cerebrospinal fluid concentration of neuron-specific enolase in diagnosis of Creutzfeldt-Jakob disease, Lancet 345 (1995), 1609-1610.

[98] R.W. Kuncl, M.M. Bilak, S.R. Bilak, A.M. Corse, W. Royal and S.P. Becerra, Pigment epithelium-derived factor is elevated in CSF of patients with amyotrophic lateral sclerosis, $J$. Neurochem. 81 (2002), 178-184.

[99] H. Tumani, R. Nau and K. Felgenhauer, Beta-trace protein in cerebrospinal fluid: a blood-CSF barrier-related evaluation in neurological diseases, Ann. Neurol. 44 (1998), 882-889.

[100] H. Tumani, H. Reiber, R. Nau, H.W. Prange, K. Kauffmann, M. Mader and K. Felgenhauer, Beta-trace protein concentration in cerebrospinal fluid is decreased in patients with bacterial meningitis, Neurosci. Lett. 242 (1998), 5-8.

[101] M. Otto, H. Stein, A. Szudra, I. Zerr, M. Bodemer, O. Gefeller, S. Poser, H.A. Kretzschmar, M. Mader and T. Weber, S-100 protein concentration in the cerebrospinal fluid of patients with Creutzfeldt-Jakob disease, J. Neurol. 244 (1997), 566-570.

[102] E.P. van Dongen, H.T. ter Beek, E.H. Boezeman, M.A. Schepens, H.J. Langemeijer and L.P. Aarts, Normal serum concentrations of S-100 protein and changes in cerebrospinal fluid concentrations of S-100 protein during and after thoracoabdominal aortic aneurysm surgery: Is S-100 protein a biochemical marker of clinical value in detecting spinal cord ischemia? J. Vasc. Surg. 27 (1998), 344-346.

[103] E.T. Lim, D. Grant, M. Pashenkov, G. Keir, E.J. Thompson, M. Soderstrom and G. Giovannoni, Cerebrospinal fluid levels of brain specific proteins in optic neuritis, Mult. Scler. 10 (2004), 261-265.

[104] A.J. Green, G. Keir and E.J. Thompson, A specific and sensitive ELISA for measuring S-100b in cerebrospinal fluid, $J$. Immunol. Methods 205 (1997), 35-41.

[105] S.E. Molchan, J.L. Hill, R.A. Martinez, B.A. Lawlor, A.M. Mellow, D.R. Rubinow, G. Bissette, C.B. Nemeroff and T. Sunderland, CSF somatostatin in Alzheimer's disease and major depression: relationship to hypothalamic-pituitary-adrenal axis and clinical measures, Psychoneuroendocrinology 18 (1993), 509-519.

[106] A. Kurz, M. Riemenschneider, K. Buch, F. Willoch, P. Bartenstein, U. Muller and W. Guder, Tau protein in cerebrospinal fluid is significantly increased at the earliest clinical stage of Alzheimer disease, Alzheimer Dis. Assoc. Disord. 12 (1998), 372-377.

[107] R.A. Lasser, R. Dukoff, J. Levy, R. Levin, T. Lehtimaki, P. Seubert and T. Sunderland, Apolipoprotein E epsilon 4 allele in association with global cognitive performance and CSF markers in Alzheimer's disease, Int. J. Geriatr. Psychiatry 13 (1998), 767-774.

[108] S. Golombowski, F. Muller-Spahn, H. Romig, K. Mendla and C. Hock, Dependence of cerebrospinal fluid Tau protein levels on apolipoprotein E4 allele frequency in patients with Alzheimer's disease, Neurosci. Lett. 225 (1997), 213-215.

[109] T. Tapiola, M. Lehtovirta, J. Ramberg, S. Helisalmi, K. Linnaranta, P. Riekkinen, Sr. and H. Soininen, CSF tau is related to apolipoprotein E genotype in early Alzheimer's disease, Neurology 50 (1998), 169-174. 
[110] S. Nagamitsu, T. Matsuishi, T. Kisa, H. Komori, M. Miyazaki, T. Hashimoto, Y. Yamashita, E. Ohtaki and H. Kato, CSF beta-endorphin levels in patients with infantile autism, $J$. Autism Dev. Disord. 27, (1997) 155-163.

[111] P. Davidsson, R. Jahn, J. Bergquist, R. Ekman and K. Blennow, Synaptotagmin, a synaptic vesicle protein, is present in human cerebrospinal fluid: a new biochemical marker for synaptic pathology in Alzheimer disease? Mol. Chem. Neuropathol. 27 (1996), 195-210.

[112] M. Otto, J. Wiltfang, H. Tumani, I. Zerr, M. Lantsch, J. Kornhuber, T. Weber, H.A. Kretzschmar and S. Poser, Elevated levels of tau-protein in cerebrospinal fluid of patients with Creutzfeldt-Jakob disease, Neurosci. Lett. 225 (1997), 210 212.

[113] X. Yuan, T. Russell, G. Wood and D.M. Desiderio, Analysis of the human lumbar cerebrospinal fluid proteome, Electrophoresis 23 (2002), 1185-1196.

[114] D. Dumont, J.P. Noben, J. Raus, P. Stinissen and J. Robben, Proteomic analysis of cerebrospinal fluid from multiple sclerosis patients, Proteomics 4 (2004), 2117-2124.

[115] M. Ramstrom, M. Palmblad, K.E. Markides, P. Hakansson and J. Bergquist, Protein identification in cerebrospinal fluid using packed capillary liquid chromatography Fourier transform ion cyclotron resonance mass spectrometry, Proteomics 3 (2003), 184-190.

[116] E.J. Finehout, Z. Franck and K.H. Lee, Towards twodimensional electrophoresis mapping of the cerebrospinal fluid proteome from a single individual, Electrophoresis $\mathbf{2 5}$ (2004), 2564-2575.

[117] J. Raymackers, A. Daniels, B.V. De, C. Missiaen, M. Dauwe, P. Verhaert, E. Vanmechelen and L. Meheus, Identification of two-dimensionally separated human cerebrospinal fluid proteins by $\mathrm{N}$-terminal sequencing, matrix-assisted laser desorption/ionization-mass spectrometry, nanoliquid chromatography-electrospray ionization-time of flight-mass spectrometry, and tandem mass spectrometry, Electrophoresis 21 (2000), 2266-2283.

[118] B.R. Wenner, M.A. Lovell and B.C. Lynn, Proteomic analysis of human ventricular cerebrospinal fluid from neurologically normal, elderly subjects using two-dimensional LC-MS/MS, J. Proteome. Res. 3 (2004), 97-103.

[119] A. Sickmann, W. Dormeyer, S. Wortelkamp, D. Woitalla, W. Kuhn and H.E. Meyer, Identification of proteins from human cerebrospinal fluid, separated by two-dimensional polyacrylamide gel electrophoresis, Electrophoresis 21 (2000), 27212728.

[120] C. Hesse, C.L. Nilsson, K. Blennow and P. Davidsson, Identification of the apolipoprotein E4 isoform in cerebrospinal fluid with preparative two-dimensional electrophoresis and matrix assisted laser desorption/ionization-time of flight-mass spectrometry, Electrophoresis 22 (2001), 1834-1837.

[121] P. Davidsson, L. Paulson, C. Hesse, K. Blennow and C.L. Nilsson, Proteome studies of human cerebrospinal fluid and brain tissue using a preparative two-dimensional electrophoresis approach prior to mass spectrometry, Proteomics 1 (2001), 444-452.

[122] P. Davidsson, A. Westman, M. Puchades, C.L. Nilsson and K. Blennow, Characterization of proteins from human cerebrospinal fluid by a combination of preparative twodimensional liquid-phase electrophoresis and matrix-assisted laser desorption/ionization time-of-flight mass spectrometry, Anal. Chem. 71 (1999), 642-647.

[123] P. Davidsson, S. Folkesson, M. Christiansson, M. Lindbjer, B. Dellheden, K. Blennow and A. Westman-Brinkmalm, Identification of proteins in human cerebrospinal fluid using liquidphase isoelectric focusing as a prefractionation step followed by two-dimensional gel electrophoresis and matrix-assisted laser desorption/ionisation mass spectrometry, Rapid Commun. Mass Spectrom. 16 (2002), 2083-2088.

[124] B.N. Hammack, K.Y. Fung, S.W. Hunsucker, M.W. Duncan, M.P. Burgoon, G.P. Owens and D.H. Gilden, Proteomic analysis of multiple sclerosis cerebrospinal fluid, Mult. Scler. $\mathbf{1 0}$ (2004), 245-260.

[125] M.G. Harrington, R. Aebersold, B.M. Martin, C.R. Merril and L. Hood, Identification of a brain-specific human cerebrospinal fluid glycoprotein, beta-trace protein, Appl. Theor. Electrophor. 3 (1993), 229-234.

[126] P.R. Burkhard, N. Rodrigo, D. May, R. Sztajzel, J.C. Sanchez, D.F. Hochstrasser, E. Schiffer, A. Reverdin and J.S. Lacroix, Assessing cerebrospinal fluid rhinorrhea: a two-dimensional electrophoresis approach, Electrophoresis 22 (2001), 18261833.

[127] E. Tarkowski, R. Issa, M. Sjogren, A. Wallin, K. Blennow, A. Tarkowski and P. Kumar, Increased intrathecal levels of the angiogenic factors VEGF and TGF-beta in Alzheimer's disease and vascular dementia, Neurobiol. Aging 23 (2002), 237-243.

[128] P. Lescuyer, L. Allard, C.G. Zimmermann-Ivol, J.A. Burgess, S. Hughes-Frutiger, P.R. Burkhard, J.C. Sanchez and D.F. Hochstrasser, Identification of post-mortem cerebrospinal fluid proteins as potential biomarkers of ischemia and neurodegeneration, Proteomics 4 (2004), 2234-2241.

[129] R.H. Aebersold, G. Pipes, L.E. Hood and S.B. Kent, Nterminal and internal sequence determination of microgram amounts of proteins separated by isoelectric focusing in immobilized pH gradients, Electrophoresis 9 (1988), 520-530.

[130] O. Carrette, I. Demalte, A. Scherl, O. Yalkinoglu, G. Corthals, P. Burkhard, D.F. Hochstrasser and J.C. Sanchez, A panel of cerebrospinal fluid potential biomarkers for the diagnosis of Alzheimer's disease, Proteomics 3 (2003), 14861494.

[131] M. Puchades, A. Westman, K. Blennow and P. Davidsson, Analysis of intact proteins from cerebrospinal fluid by matrixassisted laser desorption/ionization mass spectrometry after two-dimensional liquid-phase electrophoresis, Rapid Commun. Mass Spectrom. 13 (1999), 2450-2455. 


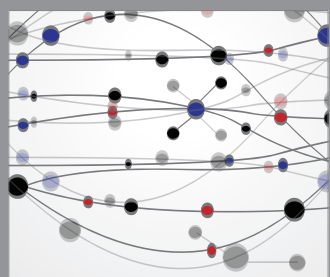

The Scientific World Journal
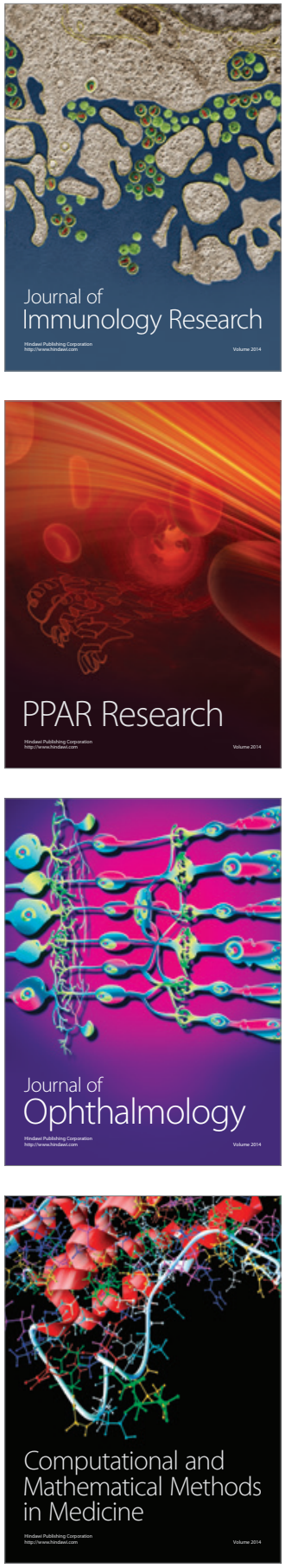

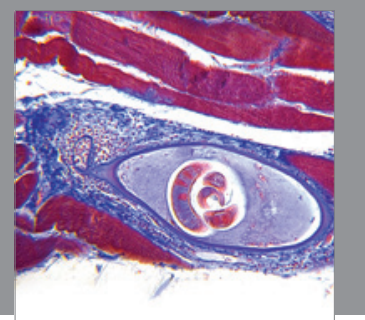

Gastroenterology

Research and Practice
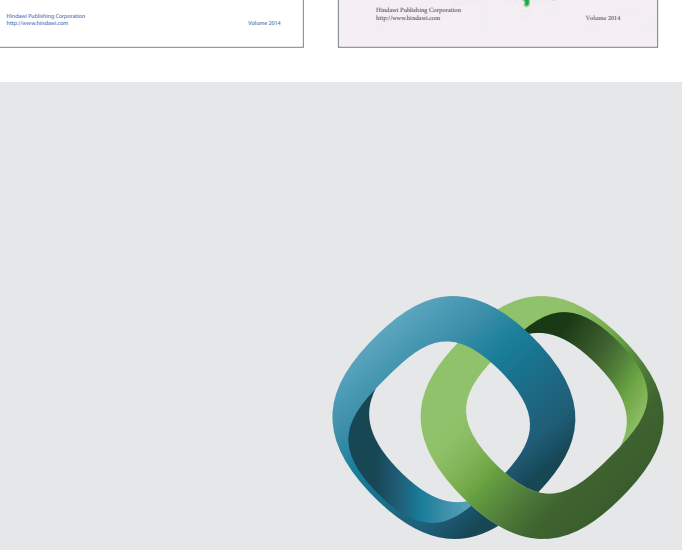

\section{Hindawi}

Submit your manuscripts at

http://www.hindawi.com
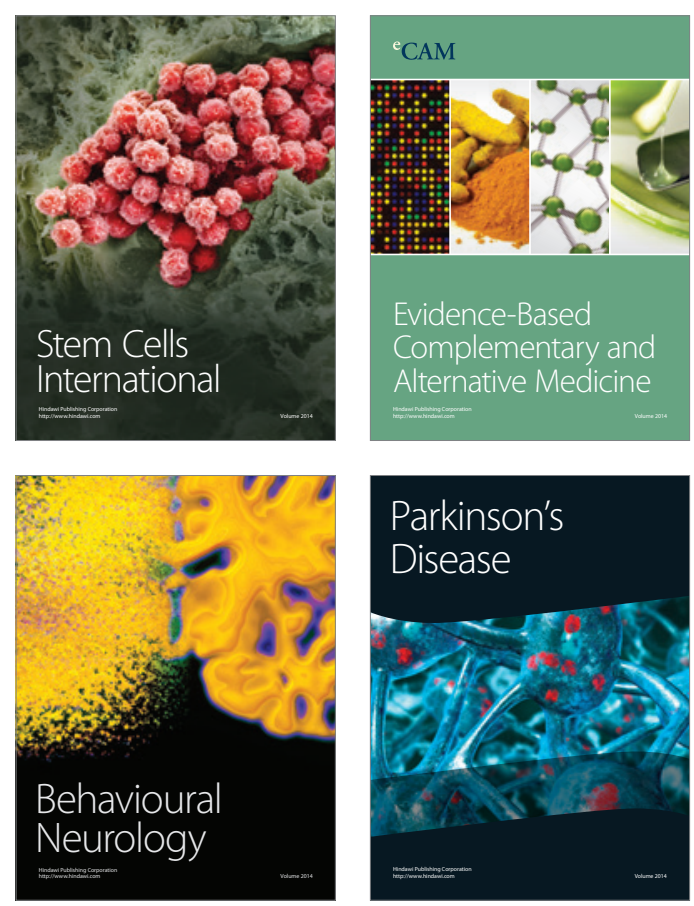

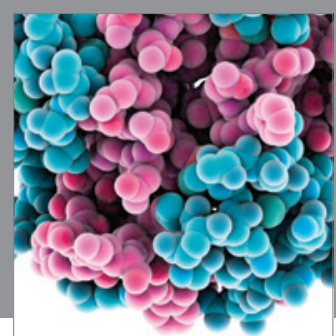

Journal of
Diabetes Research

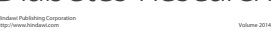

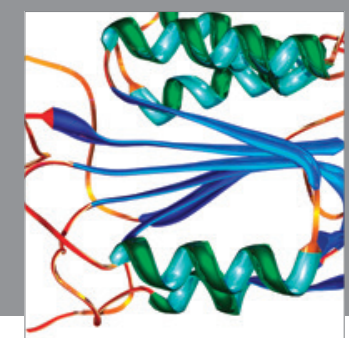

Disease Markers
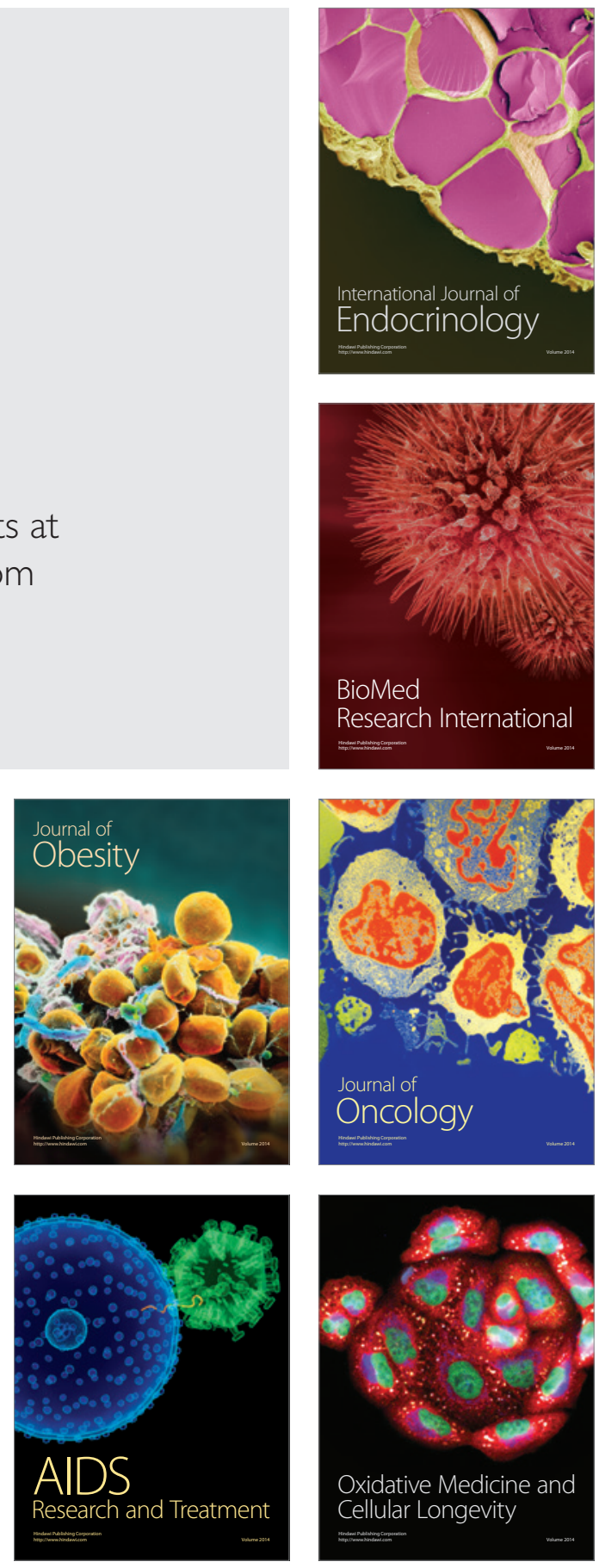